\title{
The Role of Extracellular Vesicles as Allies of HIV, HCV and SARS Viruses
}

\author{
Flavia Giannessi $\mathbb{D}^{\text {, Alessandra Aiello }} \mathbb{D}$, Francesca Franchi ${ }^{\mathbb{D}}$, Zulema Antonia Percario $\mathbb{D}$ \\ and Elisabetta Affabris * D
}

Department of Science, Roma Tre University, 00146 Rome, Italy; flavia.giannessi@uniroma3.it (F.G.); alessandra.aiello@uniroma3.it (A.A.); fra.franchi@stud.uniroma3.it (F.F.); zulema.percario@uniroma3.it (Z.A.P.)

* Correspondence: elisabetta.affabris@uniroma3.it; Tel.: +39-06-57336341

Received: 30 April 2020; Accepted: 20 May 2020; Published: 22 May 2020

\begin{abstract}
Extracellular vesicles (EVs) are lipid bilayer-enclosed entities containing proteins and nucleic acids that mediate intercellular communication, in both physiological and pathological conditions. EVs resemble enveloped viruses in both structural and functional aspects. In full analogy with viral biogenesis, some of these vesicles are generated inside cells and, once released into the extracellular milieu, are called "exosomes". Others bud from the plasma membrane and are generally referred to as "microvesicles". In this review, we will discuss the state of the art of the current studies on the relationship between EVs and viruses and their involvement in three important viral infections caused by HIV, HCV and Severe Acute Respiratory Syndrome (SARS) viruses. HIV and HCV are two well-known pathogens that hijack EVs content and release to create a suitable environment for viral infection. SARS viruses are a new entry in the world of EVs studies, but are equally important in this historical framework. A thorough knowledge of the involvement of the EVs in viral infections could be helpful for the development of new therapeutic strategies to counteract different pathogens.
\end{abstract}

Keywords: extracellular vesicles; exosomes; HIV; HCV; SARS viruses; coronaviruses

\section{Introduction}

Extracellular vesicles (EVs) are heterogeneous and polyhedral lipid bilayer-enclosed structures released by healthy, malignant or infected cells into the extracellular environment, with different origins, sizes and compositions [1]. Soon after their first observation by Chargaff and West in 1940s, EVs were considered as mere cellular "dust". Gradually, numerous studies have recognized them as multi-molecular messengers acting in both autocrine and paracrine manners, and even at great distance, modifying the activity and/or phenotype of recipient cells [2]. EVs have been isolated from most cell types and biological fluids including blood, urine, saliva, breast milk, and cerebrospinal and synovial fluid [3-7]. In physiological conditions, they are involved in antigen presentation [8], neuronal communication and protection [9], blood coagulation [10], wound healing [11], sperm maturation [12] and regulation of the immune response against the fetus during pregnancy [13]. On the other hand, EVs play a key role also in pathogenic processes including cancer [14], autoimmune diseases [15], inflammation [16], as well as in viral infections [17]. Pathogens like viruses seem to take advantage of the natural inclination of host cells to release EVs to transport their own genetic material or proteins, thus avoiding their recognition as non-self-molecules by the immune system. Therefore, EVs can play significant roles during viral infections by promoting the survival and propagation of the virus inside the host.

In this review, we provide an overview of the relationship between EVs and enveloped viruses, focusing our attention on HIV, HCV and SARS viruses. 


\section{Definition, Biogenesis and Composition of EVs}

Based on their biogenesis, EVs have been divided into three subgroups: exosomes, microvesicles and apoptotic bodies. Exosomes correspond to intraluminal vesicles (ILVs), which are generated in late endosomes by the inward invagination of their membranes, giving rise to the formation of high-density structures named multivesicular bodies (MVBs). Once formed, ILVs can meet two different fates: they can be degraded when MVBs fuse with lysosomes, or they can be released into the extracellular space upon fusion of MVBs with the plasma membrane. In the latter case, ILVs are called exosomes (size between 30-150 nm) (reviewed by [18,19]). The term microvesicles (size between 50-1000 nm) generally refers to vesicles that bud directly from the plasma membrane, while apoptotic bodies (size between $50 \mathrm{~nm}$ to $5 \mu \mathrm{m}$ ) are vesicles generated by cells undergoing apoptosis $[19,20]$.

Among the different types of EVs, exosomes are the best characterized. However, the processes leading to the generation of ILVs in MVBs and their fusion with the plasma membrane are not completely known. To date, two independent pathways have been proposed. The first one is accomplished by components of the Endosomal Sorting Complex Required for Transport (ESCRT), a molecular machinery made up by four multiprotein complexes (ESCRT-0, -I, -II, -III) and accessory proteins (i.e., Alix and VPS4) [21,22]. The second pathway for the biogenesis of exosomes is ESCRT-independent and involves tetraspanins (such as CD9, CD63, CD81 and CD82), a superfamily of proteins characterized by four transmembrane domains, and lipid molecules, such as ceramide, a conic lipid that facilitates membrane invagination [23,24]. The biogenesis of microvesicles differs considerably from that of exosomes. Prior to their shedding at the plasma membrane, cytoplasmic protrusions are generated by the cell, which undergoes fission events and, finally, microvesicles pinch off the cellular membrane [25]. The mechanisms underlying these shedding events are not well elucidated yet; however, microdomain-induced budding processes seem to be involved in their secretion. Recently, Shurer and colleagues suggested also a role for glycocalyx in regulating curved membrane features and driving the secretion of EVs ranging in size from approximately $100 \mathrm{~nm}$ to $400 \mathrm{~nm}$ [26]. Not by chance, enterocytes, reactive astrocytes, dendritic cells, and tumor cells, on whose surfaces mucins and hyaluronan polymers are densely arrayed, usually secrete high levels of vesicles [27-32]. According to what was reported by Shurer et al. [26], the glycocalyx would enable cytoskeletal filaments to extend and stabilize thin protrusions from the plasma membrane, and then spontaneous curvature imposed by the glycocalyx would induce the formation of membrane pearls that spontaneously fissure to release vesicles.

The important role played by EVs as potent vehicles of intercellular communication is mainly linked to their ability to carry a wide range of biological macromolecules such as proteins, lipids, and nucleic acids. Regarding nucleic acids, DNA fragments, single and double-stranded DNAs, mitochondrial DNA and RNA species, such as mRNAs, miRNAs and a great variety of small non-coding RNAs, have been detected in EVs [33-35]. Notably, emerging studies have also identified the release of EVs as a potential mechanism by which cytokines/chemokines can be secreted. Representative examples are Interleukins $1 \beta$ (IL-1 $\beta$ ) and IL-18, both secreted upon inflammasome activation, macrophage migration inhibitory factor (MIF), IL-32 and Tumor Necrosis Factor (TNF) family members. Interestingly, Interferon family members (IFNs) have also been detected in EVs (for a comprehensive review, see [36]).

Interestingly, in addition to self-molecules, EVs can be carriers of microbial components, including viral ones [34]. The encapsulation of molecules, both self and non-self, into EVs could protect them from enzymatic degradation and the recognition as danger signals during their transit into the extracellular milieu, thus facilitating their delivery at distant target cells.

\section{EVs and Viruses: Close Relatives?}

In recent decades, the similarity between EVs and viral particles has become increasingly evident. Viruses and EVs share different aspects such as size, structural and biochemical composition, and the transport of bioactive molecules within cells $[34,35]$. Like EVs, viruses present a size ranging from 30 to $1000 \mathrm{~nm}$, starting from the small ones, such as poliovirus and hepatitis A virus (HAV) particles, 
which possess a diameter of about $30 \mathrm{~nm}$, all the way to hepatitis $\mathrm{C}$ virus (HCV) of about $50 \mathrm{~nm}$, and HIV or SARS viruses that are about $100-120 \mathrm{~nm}$. Finally, mimiviruses have a size of about $400 \mathrm{~nm}$. Furthermore, EVs and some viruses have morphological similarities: as previously described, EVs are double-membrane-enclosed entities and enveloped viruses are also surrounded by a lipid membrane acquired from the cell. Interestingly, they possess a similar lipid composition enriched in glycosphingolipids and cholesterol, as well as a similar protein content. Notably, both EVs and viruses carry nucleic acids; while viruses present single or double-stranded RNA or DNA genomes, which are carried and protected inside their capsid, EVs can transport a variety of nucleic acids [35,37,38]. EVs and enveloped viruses also share similar biogenesis processes since both are generated in the endosomal network or bud from the plasma membrane using specific pathways [18]. For example, some retroviruses such as HIV hijack the cellular vesiculation machinery to favor their own replication and budding. In this regard, it has been reported that the endosomal sorting complex (ESCRT), the same that mediates the inward invagination of ILVs in MVBs, is also involved in the budding and release of HIV particles [39,40]. Moreover, just as EVs can be generated from ESCRT-independent pathways, some viruses bud from specific membrane domains [41]. These domains, called lipid rafts, are enriched in glycosphingolipids, cholesterol and ceramide. In addition, proteins like tetraspanins are stored in these domains and form clusters among themselves and other transmembrane and cytosolic proteins, thus inducing inward budding of the microdomains in which they are enriched [42]. As previously mentioned, specific glycocalyx compositions also play a role in vesicle release; however, glycocalyx can be also involved in other membrane processes, including the absorption of some viruses [43]. In this regard, some viruses have evolved to exploit specific glycans to enter cells, like human rotaviruses that bind the blood group A antigens [44]. Instead, in the case of HIV [45], Ebola virus [46], HCV [47], as well as influenza [48] or Severe Acute Respiratory Syndrome (SARS) viruses [49], the viruses themselves present glycans on their surface. Their presence on viral surfaces is exploited by immune cells, such as macrophages or dendritic cells, to phagocyte virions. In turn, Ebola [46] and SARS viruses [49] take advantage of this anti-viral system to enter and replicate in macrophages and dendritic cells. On the other hand, glycans are also used by viruses to create a shield that hides viral epitopes to immune cells, as happens with HIV, known to have the highest density of glycans attached to its surface proteins [50], and the Lassa virus [51].

The substantial overlap of the biogenesis processes provides a plausible explanation for the similar composition observed between EVs and enveloped viruses [39]. Furthermore, both EVs and enveloped viruses can bind to the plasma membrane of recipient cells and, after fusion events, directly with the surface membrane or after endocytosis, they release their luminal cargo into the cytosol, influencing cell activity [18]. In this respect, in a similar manner to the viral envelope proteins, EV surface proteins, such as the intercellular adhesion molecule 1 (ICAM-1), mediate the adhesion and internalization of EVs in target cells [52]. Therefore, both EVs and viruses can be considered as bioactive structures able to influence the cellular behavior.

The presence of multiple similarities between viruses (in particular retroviruses) and EVs, immediately triggered conjecture on the real relationship between vesicles and viruses. For this reason, two alternative theories have been proposed. The first one, called the "Trojan exosome hypothesis", states that retroviruses are vesicles evolved following a mutation of the gag gene, which was originally encoded by an integrated retro-transposon that directed its expression product towards the route of vesicle generation. In this perspective, the typical characteristics of retroviruses would have been acquired by evolutionary divergence; the pre-existing biogenesis mechanism of vesicle production would have been used to form viral particles [53]. The second theory does not associate viruses to modified exosomes. It justifies the similarities, giving more importance to the phenomenon of convergent evolution, which would lead to the sharing of the same biogenesis pathways for vesicles and viruses [54]. Both theories provide a plausible justification for the affinities observed between viruses and EVs. However, regardless of their possible origin, these affinities certainly have a negative 
impact on immunological surveillance in the host, since viruses, during infections, can take advantage of these affinities for escaping the immune system by mimicking vesicle composition and behavior [55].

The remarkable resemblance between EVs and viruses has caused quite a few problems in the studies focused on the analysis of EVs released during viral infections. Nowadays, it is an almost impossible mission to separate EVs and viruses by means of canonical vesicle isolation methods, such as differential ultracentrifugation, because they are frequently co-pelleted due to their similar dimension [56,57]. To overcome this problem, different studies have proposed the separation of EVs from virus particles by exploiting their different migration velocity in a density gradient or using the presence of specific markers that distinguish viruses from EVs [56,58,59]. However, to date, a reliable method that can actually guarantee a complete separation does not exist.

\section{Vesicles as Mediators of a Suitable Environment for Viral Infections}

Studies conducted on exosomes and other EVs, isolated during a variety of infections caused by bacteria, parasites and viruses, have evidenced changes in the composition and biological activity of EVs [34]. In recent years, the relevance of vesicles in viral infections has been strongly highlighted, because EVs may incorporate viral proteins and/or fragments of viral RNAs, carrying them from infected cells to target ones $[23,33,60]$. Importantly, even if the viral hijacking of EVs contributes to create a suitable environment for viral survival through the suppression and evasion of the immune response, EVs can be involved in the induction of an antiviral response. Therefore, vesicles can play a dual role-both supporting viral spreading and inducing immunological protection [34]. Next we focused our attention on how vesicles can support viruses during infections. Some picornaviruses, such as HAV, Coxsackie B virus and Enterovirus 71 (EV71), can be released inside vesicles [61-65] (see Figure 1a). They are non-enveloped viruses but, when released inside EVs, they acquire a kind of "cellular envelope". EV enveloped viruses probably take advantage of the membrane coating to avoid the recognition by neutralizing antibodies. In addition, these viruses could use cellular surface proteins to extend their own tropism, thus succeeding in reaching the most disparate districts in the host [33]. Instead, HIV and HCV seem to exploit EVs both directly and indirectly. They directly manipulate the machinery of vesicular biogenesis to enhance viral replication. Indirectly, they can charge exosomes and other vesicles with different viral components, thus favoring viral pathogenesis $[23,66]$ (see Figure 1b,c). The dynamics of the influence of EVs on HIV and HCV infection will be discussed later and in detail.

Another well-known example is Epstein-Barr virus (EBV), a DNA virus that exploits vesicular production to block the antiviral response. As happens in HIV and HCV infections, EBV-infected cells release vesicles enriched with viral proteins, including Latent Membrane Protein 1 (LMP1), a pro-oncogenic protein that acts as deregulator of cellular transduction pathways by promoting EBV-infected B lymphocyte transformation and immortalization, as well as a global immune modulation [33,67-69]. LMP1 was found in vesicles collected from in vitro infected cells and from serum of patients with EBV-associated nasopharyngeal carcinoma [67,68,70]. A common belief is that LMP1 is selectively charged into EVs thanks to its localization in lipid rafts and its interaction with CD63, a well-known tetraspanin abundantly found in vesicles [71-73]. LMP1-containing EVs secreted by $B$ cells inhibit $\mathrm{T}$ and natural killer (NK) cell proliferation, thus reducing the immune response against the virus $[68,74]$. Also, these EVs upregulate the expression of adhesion molecules in uninfected cells, increasing their susceptibility to the infection [75]. Moreover, EVs released from EBV-infected cells can contain viral nucleic acids [76,77]. In particular, different RNAs have been found: miR-BART15-3p, which induces apoptosis in target cells, including the immune ones [78]; miRNA BHRF1, which suppresses the expression of the chemokine CXCL11 involved in antiviral activity [79]; the non-coding RNAs, EBER1 and EBER2, that support the survival and carcinogenesis of infected cells by avoiding cell apoptosis [80].

Some viruses do not influence the encapsulation of viral proteins into vesicles, but control the packaging of host factors (see Figure 1d). This occurs in the case of Kaposi's sarcoma-associated herpesvirus (KSHV/HHV-8). EVs released by KSHV-infected cells are enriched in metabolic proteins, 
such as lactate dehydrogenase, and in proteins affecting the immune system such as the cleaved forms of IL-1 and IFI16 [81,82]. Consequently, KSHV-EVs alter the metabolism and the innate immune response in recipient cells, facilitating viral persistence.

Cytomegalovirus (CMV) and herpes simplex virus 1 (HSV-1) usually exploit modified EVs as well. For instance, EVs from CMV-infected cells deliver proteins, such as lectin and dendritic cell-specific intercellular adhesion molecule-3 grabbing non-integrin (DC-SIGN), involved in the capture and internalization of pathogens [83]. HSV-1 EVs carry the viral glycoprotein B that reduces the surface expression of HLA-DR, a MHC class II cell surface receptor, by directing it into the vesicular network to avoid viral recognition by the immune system [84]. Additionally, they transport different viral mRNAs and miRNAs [85].

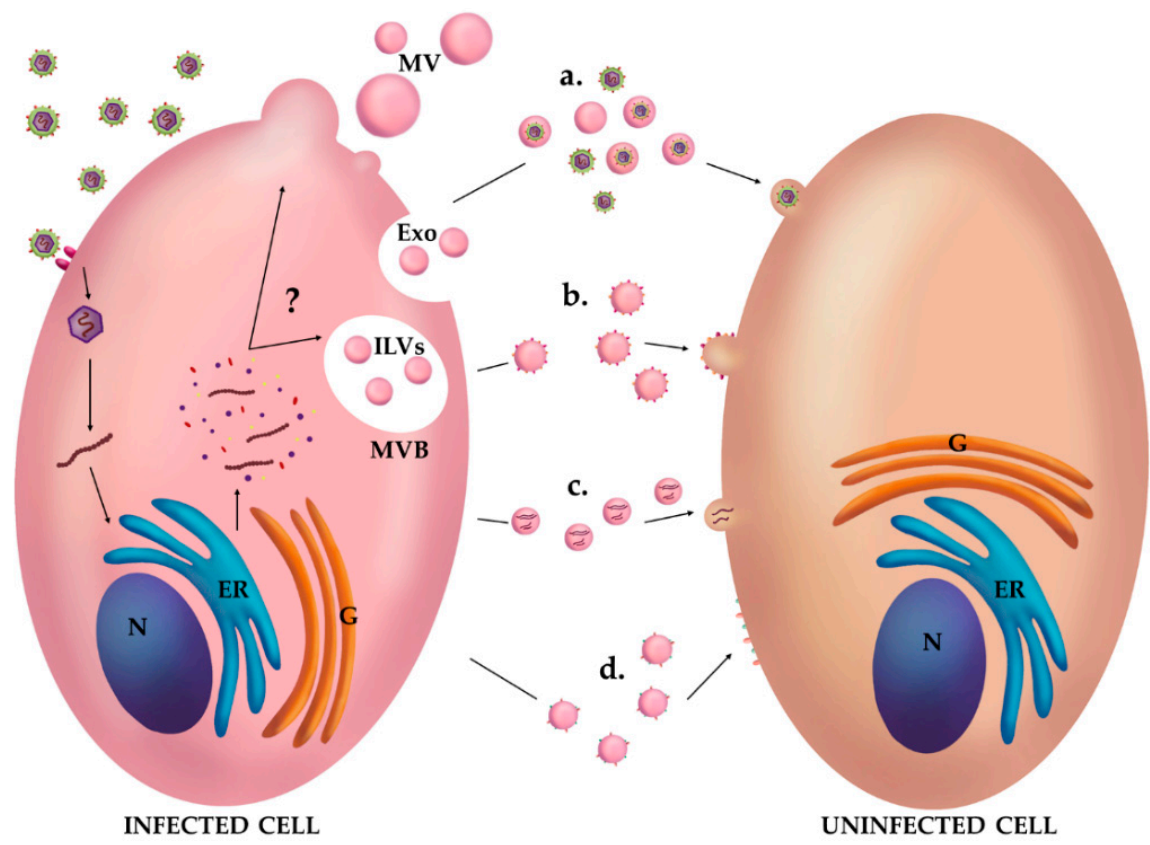

Figure 1. EVs are vehicles for the communication between infected and uninfected cells. During viral infections, virus enters cells and exploits the vesicular biogenesis machinery to release EVs, microvesicles (MV) and exosomes (Exo) with a modified composition to favor its own pathogenesis. EVs can carry (a) entire viral particles; (b) different viral proteins, such as the envelope ones; (c) nucleic acids including viral genomes, microRNAs and small non-coding RNAs and (d) host cell proteins, whose production is induced by the virus. Finally, EVs are internalized through different mechanisms and their luminal content released into the cytosol of the recipient cells. Nucleus (N); endoplasmic reticulum (ER); Golgi complex (G); multivesicular bodies (MVB); intraluminal vesicles (ILVs).

\subsection{The Case of HIV}

Human immunodeficiency virus (HIV) is a retrovirus recognized as the etiological agent of Acquired Immune Deficiency Syndrome (AIDS), a progressive pathology that induces a weakening of the host immune system. The virus is characterized by two identical copies of a positive-sense single-stranded-RNA enclosed in a viral nucleocapsid, called a core, which is surrounded by a membrane envelope [86]. The genome codifies for three structural protein precursors, Gag, Pol and Env, the two regulatory proteins Tat and Rev, and the four accessory proteins Nef, Vif, Vpr, and Vpu. All these factors differently contribute to the establishment of HIV infection [87]. The main targets of the virus are the immune cells such as Thelper lymphocytes, macrophages, microglial and dendritic cells, which express on their plasma membrane the CD4 receptor used by the virus to bind and enter the cells. HIV persists inside the host, leading to a progressive impairment of the immune system because of the depletion of $\mathrm{CD} 4^{+} \mathrm{T}$ helper cells, finally resulting in AIDS [86]. 
In recent years, different studies have highlighted the potential roles of EVs in HIV pathogenesis. The virus can take advantage of the endomembrane system not only by enhancing the viral biogenesis itself, but also by inducing EV biogenesis changes. These modifications may involve alterations in cargo composition, the frequency of EV release and targets, thus promoting viral spread, replication, and immune evasion (see Figure 2). In this respect, different studies have showed how EVs released from infected cells can deliver the HIV co-receptors CCR5 and CXCR4 to other cells, making them susceptible to the viral infection, probably increasing the tropism of the virus in vivo and favoring its dissemination $[88,89]$. Furthermore, EVs can facilitate infection through association with viral progeny, thus camouflaging the viral particles and reducing recognition by the immune system.

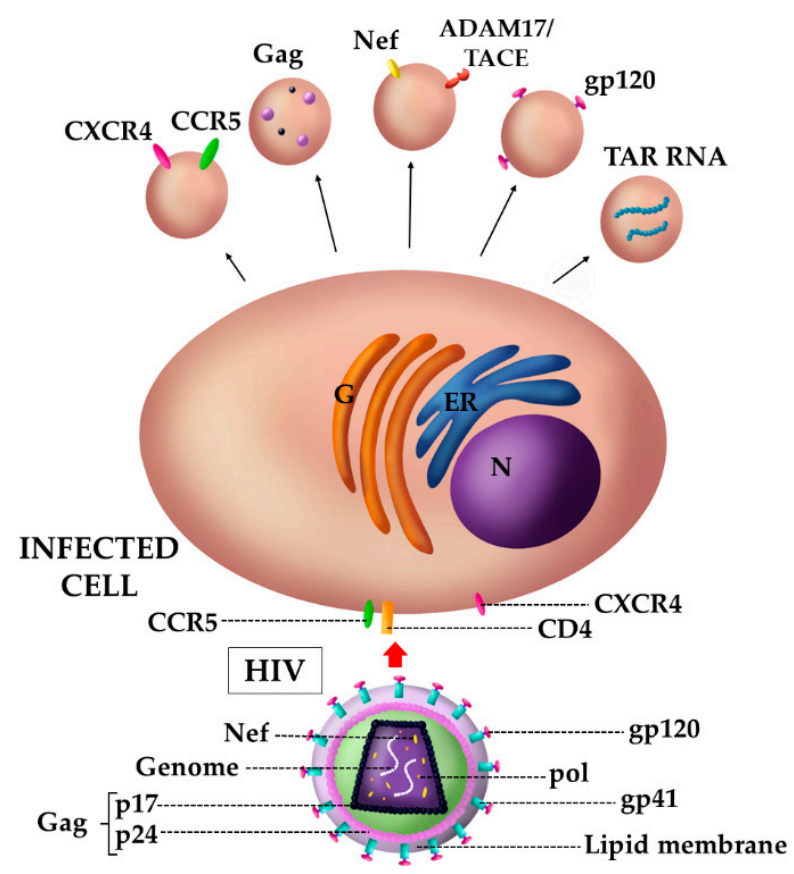

Figure 2. Schematic representation of EVs released by HIV-infected cells. EVs derived from HIV-infected cells carry both viral and host cell components that favor viral spreading and HIV-associated immune pathogenesis. Regarding host proteins, EVs transfer the two co-receptors CCR5 and CXCR4, used by the virus to mediate its entry, to null cells. Among viral components, EVs carry the proteins Gag, gp120 and Nef, as well as Trans-Activation Response (TAR) RNA, a pre-microRNA that produces mature microRNAs. Nef protein also induces the uploading into EVs of ADAM17/TACE, a TNF $\alpha$ converting enzyme. Nucleus (N); endoplasmic reticulum (ER); Golgi complex (G).

Regarding HIV-EV cargo, different viral proteins have been reported to be encapsulated in extracellular vesicles, including the virulence factor Nef, which has gained a great attention. Nef acts as molecular adaptor in both infected and uninfected cells by exerting multiple effects depending on its intracellular localization. The most important and best characterized functions of Nef are: (a) modulation of the expression of different surface receptors; (b) induction of a pre-activation state in $\mathrm{CD}^{+} \mathrm{T}$ cells, resulting in the increase in their susceptibility to the infection and promotion of viral gene expression; (c) regulation of apoptosis by inducing it in bystander uninfected cells meanwhile protecting infected cells; (d) regulation of the cytokine network contributing to chronic inflammation and, finally, (e) the increase in the infectivity of released HIV virions by preventing the incorporation of two antiviral proteins, SERINC3 and SERINC5 [87,90,91]. Interestingly, Nef also plays an important role in the vesicular network; it can influence the endosomal trafficking, being incorporated into MVBs, and induce late endosome formation. Not by chance, Nef binds and activates the PI3 kinase involved in vesicular formation [92]. In particular, Nef influences the production of vesicles and exploits them for its transport [93]. Different studies have shown how Nef increases vesicular production $[94,95]$ and its association with EVs, which was observed both in 
in vitro and in vivo studies [94-96]. Interestingly, vesicles containing Nef turned out to exert multiple pathogenic effects: the induction of T-cell apoptosis [94]; the down-modulation of cell surface molecules (i.e., MHC-I and CD4) to favor immune evasion [97], and the restoration of the infectivity of HIV particles defective in Nef protein [98]. Furthermore, Nef binds and incorporates into vesicles the TNF $\alpha$ converting enzyme (ADAM17 or TACE) $[99,100]$, a metalloprotease that cuts the pro-TNF $\alpha$ present in cell membranes, causing the release of the active form of TNF $\alpha$. Nef-EVs, by inducing $\mathrm{TNF} \alpha$ release, promote the activation of resting cells, such as $\mathrm{CD}^{+} \mathrm{T}$ lymphocytes, making them competent for HIV expression and replication [101-103]. A similar mechanism was also found to be involved in the reactivation of cells latently infected with HIV-1 [104]. These mechanisms have probably a great relevance in vivo, since Nef-EVs charged with ADAM17 and other pro-inflammatory factors appear to correlate with HIV-associated immune pathogenesis in both viremic and non-viremic chronic infection [99,103]. Noteworthy, HIV infection can also cause chronic neurological diseases and neurocognitive disorders (HIV-1 associated neurocognitive disorders (HAND)). Nef-containing EVs seem to be involved in the progression of these neuroimmune diseases. In chronic neurological diseases related to HIV infection, Nef-EVs released by infected microglia can disrupt the integrity of the blood-brain barrier, thus increasing its permeability, and can enhance the levels of some cytokines and chemokines such as IL-2, IL-8, IL-6, RANTES and IL-17A [105]. EVs isolated from the plasma of HAND patients can transport Nef protein and its correspondent mRNA is also able to induce the expression of the viral protein in a neuroblastoma cell line. This expression increases the production and secretion of beta amyloid protein, probably contributing to the cognitive impairment of HAND patients [96]. Overall, these data suggest that Nef-EVs are key mediators of the neuroimmune pathogenesis of HIV infection. Among the viral components transported into EVs, there is also Gag protein, which was found inside vesicles collected from infected Jurkat $\mathrm{T}$ cells, but its effects in uninfected cells are currently unknown [106]. Even gp120 envelope protein was found in EVs isolated from infected cells that seem to significantly increase the viral infectivity in human lymphoid tissues [107].

EVs released from HIV-infected cells can transport viral RNAs, which stimulate Toll like receptor-8 (TLR8) signaling to promote TNF $\alpha$ release, which may contribute to chronic immune activation [108]. Furthermore, the HIV Trans-Activation Response (TAR) RNA was found to be incorporated into EVs. TAR RNA is a microRNA precursor that matures after cleaving and its products are involved in apoptosis regulation and viral replication in infected cells. Once transferred to recipient cells, TAR microRNAs enhance the downregulation of pro-apoptotic proteins, thus supporting infected cells survival [109]. TAR-EVs have also been reported to modulate the gene expression of different pro-inflammatory cytokines, such as IL- 6 and TNF- $\beta$, in human macrophages. These cytokines allow the maintenance of a continuous state of activation of target cells, probably favoring the efficient entry and replication of the virus [110]. In conclusion, EVs from different cell sources seem to play different roles in HIV pathogenesis. The effect of EVs depends on the cargo, the type of cell from which they originate, and their interaction with viral components.

\subsection{The Case of HCV}

Hepatitis C Virus (HCV) is a human virus belonging to Flaviviridae, characterized by a positive single-stranded RNA of about $9.6 \mathrm{~kb}$. The $\mathrm{HCV}$ genome codifies a precursor protein that is cleaved in ten viral proteins, including the core protein p22, the two glycoproteins of the viral envelope (i.e., E1 and E2) and the non-structural ones. This virus has hepatic tropism and it represents one of the main causes of liver damage, since it provokes chronic hepatitis in about $80 \%$ of infected people. The pathogenesis is mainly caused by an alteration of cytokines, chemokines, and growth factors, which favor the production of the extracellular matrix (ECM) and decrease its degradation by means of metalloproteases (MMPs). These events lead to liver fibrosis that, in a variable percentage of cases, can evolve into cirrhosis and in hepatocellular carcinoma (HCC) [111]. The study of the role of EVs during HCV infection is a field still in active growth. Despite this, some potential mechanisms of these vesicles have already been identified (see Figure 3). As previously mentioned, a peculiarity of EVs 
is their ability to transfer the virus, or parts of it, to other "naive" cells, thus becoming a vehicle of viral transmission [112]. It is known that viral progeny is usually composed by infective and defective viral particles. The latter, because of random mutations, may not necessarily lead to a productive infection. In these respects, the vesicular transport can represent a real advantage for the virus, because EVs can compensate for some shortcomings [113]. For instance, when viral particles defective in anchoring glycoproteins were carried inside EVs, they could enter target cells by means of cellular proteins present on EV membranes. In this way, EVs would allow the establishment of a productive infection for defective particles. Furthermore, different studies reported that HCV exploits the cellular vesicular pathway for the assembly and release of viral particles [114], and HCV-infected cells release vesicles containing E1 and E2 envelope proteins [115], the entire viral genome [116], or even entire viral particles [117]. These vesicles, once they enter target cells, can establish a productive infection exactly as with free viral particles [118]. Considering these data, we can imagine that EVs could represent an interesting and important advantage, from an evolutionary point of view, in the generation of viral "quasispecies". The latter are collections of closely related viral genomes generated upon replication of RNA viruses, including HCV, and subjected to a continuous process of genetic variation and competition among the variants generated. Only the variants that fit best in a given environment are selected [113]. In this context, the EV cargo could help to establish a productive infection for those genomic variants that, otherwise, would be negatively selected due to the accumulated mutations that are incompatible with a successful infection. In this way, EVs might favor the survival of a major number of viral particles.

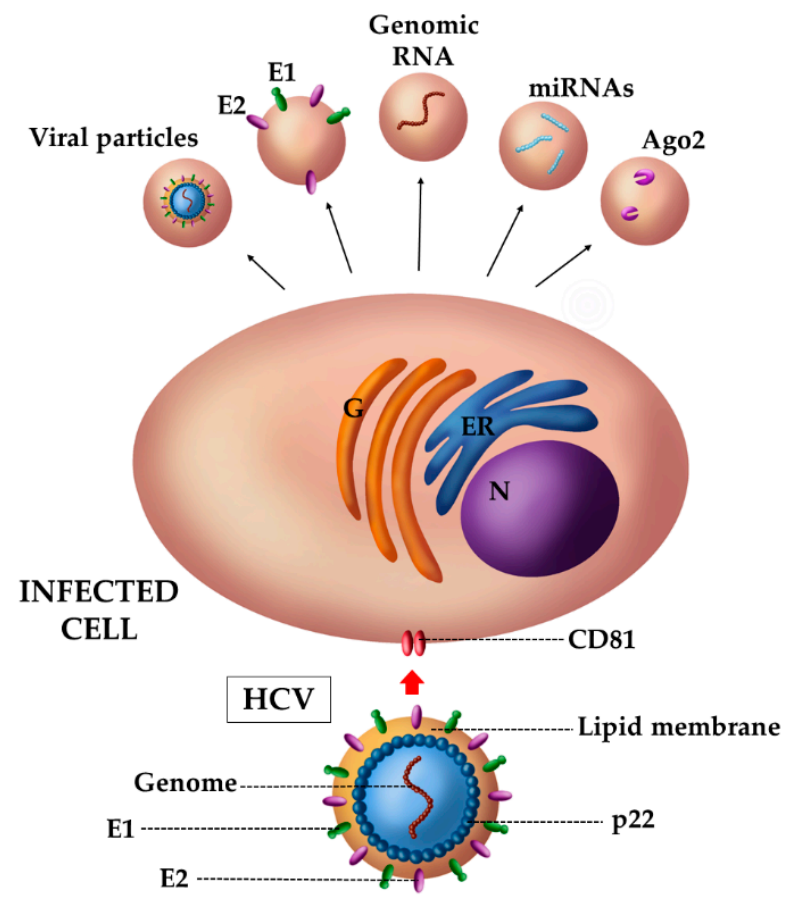

Figure 3. Schematic representation of EVs released by HCV-infected cells. EVs derived from $\mathrm{HCV}$-infected cells carry both viral and host cell components that promote viral dissemination and immune pathogenesis. HCV-EVs carry entire viral particles, thus hiding them to immune system and allowing the virus to enter the recipient cells using uncanonical receptors. In addition, HCV-EVs transfer the glycoproteins E1 and E2, viral genomes as well as miRNAs, such as miRNA-19a, miRNA-192 and miRNA-122, and host proteins including Argonaute 2 (Ago2), the effector of RNA interference (RNAi) that associates with Hsp90. Nucleus (N); endoplasmic reticulum (ER); Golgi complex (G).

Therefore, as already reported above for HIV, this uncanonical communication pathway would represent, for the virus, an advantage to disguise itself and not be recognized by the immune system, and also to enter the recipient cells using receptors other than canonical ones [112]. 
However, during an HCV infection the EV cargo is not characterized exclusively by viral components. Indeed, cytokines and additional factors, which promote an efficient viral replication, have also been detected in EVs. One of these factors is represented by microRNAs (miRNAs), 21-23 nucleotide non-coding RNA molecules that post-transcriptionally repress gene expression [119]. Various types of miRNAs have been associated with liver tissue and some of them are highly specific. For example, EVs can transport and release miRNA-192, causing phenotypic changes in the cells because of the increased production of Transforming Growth Factor $\beta$ (TGF- $\beta$ ). This cytokine is involved in the liver tissue maintenance of fibrogenesis and acts as a powerful activator of hepatic stellate cells (HSCs). TGF- $\beta$ exists in three isoforms: TGF- $\beta 1,-2,-3$, but the most representative of the fibrogenic pathways in the liver is TGF- $\beta 1$ [120]. The latter usually reduces the degradation of the extracellular matrix (ECM) thanks to the production of MMP inhibitors (TIMPs), which block the activity of matrix metalloproteases (MMPs). However, the altered production of TGF- $\beta$ leads to an increased transcription of pro-fibrotic molecules, such as alpha-smooth muscle actin ( $\alpha$-SMA) and collagen type I (COL1), through pathways involving MAPKs, JNK and Akt. These events finally cause the excessive formation of the extracellular matrix (ECM), which is responsible for the development of fibrous tissue [120]. A similar effect was observed following the release of miRNA-19a by EVs. HCV-EVs carry miR-19a and target SOCS3 in HSCs, which, in turn, activates the STAT3-mediated TGF- $\beta$ signaling pathway and enhances fibrosis marker genes [111]. Indeed, non-canonical STAT3 activation induces a higher TGF- $\beta 1$ and collagen I expression.

Furthermore, other factors such as Ago2, miR-122 and HSP90, have been found to intensify HCV replication [112]. miR-122 is one of the most abundant miRNAs in the liver tissue, representing about $70 \%$ of the total miRNA pool [119]. The key role of microRNAs is to regulate the translation of cellular mRNAs via their integration into a protein complex called RISC (RNA-induced silencing complex) with important proteins called Argonautes (Ago), of which human cells have four types: Ago1, -2, -3 and -4 [121]. Argonaute 2 (Ago2), the effector of RNA interference (RNAi), requires and associates with heat shock protein 90 (Hsp90). The latter is one of the heat shock proteins (Hsps), molecular chaperones that control the folding and function of proteins. However, it is necessary to underline that these factors potentiate viral replication, but they are not essential, since their inhibition does not prevent it.

In conclusion, these data demonstrate how the EVs released during HCV infection provide a variety of molecules that favor efficient viral replication in recipient cells [112,122].

\subsection{The Case of SARS Viruses}

Coronaviruses (CoVs) belong to a large family of enveloped RNA viruses involved in various respiratory syndromes. The name coronavirus derives from their characteristic electron microscopy appearance. They have a typical round "fringe" that recalls the solar corona, which surrounds a spherical enveloped particle containing the positive single-stranded RNA genome. The latter is complexed with the $\mathrm{N}$ viral protein, thus forming a helical symmetrical nucleocapsid complex [123]. These viruses have the largest known viral RNA genome (around $30 \mathrm{~kb}$ ). All CoVs are characterized by a common set of structural proteins: the nucleocapsid $(\mathrm{N})$, the spike $(\mathrm{S})$, the membrane $(\mathrm{M})$ and the envelope (E) proteins $[124,125]$. This type of viruses was known to cause mild to moderate diseases in humans, often characterized by cold-like symptoms and more rarely by the development of severe respiratory syndromes. However, some previously unknown species have caused epidemics with severe clinical conditions in the new millennium. This is the case of the severe acute respiratory syndrome virus (SARS-CoV), which emerged in southern China at the end of 2002; the Middle East respiratory syndrome virus (MERS-CoV), which emerged in Saudi Arabia in 2012; and now the severe acute respiratory syndrome coronavirus 2 (SARS-CoV-2), which originated in the city of Wuhan in China in December 2019 [126].

The interaction of the CoV S glycoprotein with its surface receptor is essential to determine the cellular host tropism. MERS-CoV S protein binds the human receptor dipeptidyl peptidase-4 
(DPP4) or adenosine deaminase complexing protein 2, which is expressed on the surface of the cells of the airway system. A work carried out during the first SARS-CoV epidemic identified the human host factor angiotensin-converting enzyme 2 (ACE2) as the receptor for SARS-CoV [127]. ACE2 is a metalloprotease expressed in the epithelial and alveolar cells of the human lung, in the intestine, liver, heart, vascular endothelium and kidneys [128-131]. SARS-CoV-2 spike (S) protein has been experimentally shown to bind ACE2 in host cells with significantly higher affinity than SARS-CoV $\mathrm{S}[132,133]$. The main host protease, which mediates $\mathrm{S}$ protein activation in primary target cells and allows viral entry, is the Type II transmembrane serine protease (TMPRSS2) [132,134-138]. Other host proteases, such as furin, have also been suggested to promote the pathogenesis of this pandemic SARS-CoV-2 clade, but when and where they process S protein remains to be determined [138-141]. ACE2 has a protective effect on lung safeguarding from acute injury in mouse models. The binding with SARS-CoV S induces a downregulation of ACE2 surface expression, and this mechanism possibly contributes to the severe pathogenesis of SARS viruses [142]. The immune response against CoVs has an important impact on the development of the pathogenesis. Indeed, in severe cases of SARS, the pathology is correlated to the hyperactivation of innate immune signaling. This event occurs in the abnormal production of interferons and high levels of pro-inflammatory cytokines such as IL-1, IL-6, IL-8, CXCL-10 and TNF $\alpha$, which contribute to the lung damage. In patients with severe SARS disease, aberrant IFN, Interferon Stimulated Genes (ISGs), and cytokine responses were observed compared to healthy individuals, thus providing evidence that SARS is an innate immune response-regulated disease [143]. Recently, Ziegler et al. [144] have described that ACE2 is an ISG in specific human, but not murine, airway epithelial cells. Indeed, by treating primary human upper airway basal cells with distinct types of inflammatory cytokines, they unexpectedly observed that IFN- $\alpha$ drives the ACE2 expression. This discovery, along with SARS-CoV-2 utilizing host ACE2 to gain entry to cells, suggests that SARS-CoV and SARS-CoV-2 may exploit the ACE2-mediated tissue-protective response to provide further cellular targets [144]. This potential strategy employed by SARS-CoV-2 could represent a unique challenge for the human host, as well as for HCoV-OC43, which targets the two restriction factors IFITM2 and IFITM3 [145]. Ziegler at al. provide a motivation to understand the specific role and balance of Type I and Type II IFNs, as well as Type III IFNs, in tissue protection during SARS-CoV-2 infection [144]. Carefully controlled clinical trials will be essential to determine the overall effects of different IFNs [146]. One study on SARS-CoV suggested the timing of the Type I IFN response as a key component of the in vivo response [147]. Clinical therapy using approved IFNs has been attempted for SARS-CoV, MERS-CoV and SARS-CoV-2 in the absence of a controlled trial and showed a mixed response, i.e., suggesting either rapid improvement or the worsening of symptoms [148-150].

After binding to cell surface receptors, CoVs enter cells through receptor-mediated endocytosis. Subsequently, the translation occurs and two large polyproteins are produced and cleaved. Different nonstructural proteins (Nsps), with enzymatic activity that are involved in the genome replication and expression, are generated. The Nsps are recruited together with host cell proteins to form the membrane-associated replication and transcription complexes (RTCs). The presence of RTCs allows the accumulation of different mRNAs that are translated in structural and non-structural viral proteins. Once they are produced in sufficient amounts, the virus is assembled and buds on the membrane of the endoplasmic reticulum (ER) and Golgi, where the membrane M, E and S viral proteins are accumulated. Finally, viral particles are released into the lumen of host cell membranous compartments and, afterwards, virions are released into the extracellular space via secretory pathways [131,151].

Although these second-millennium CoVs are some of the most pathogenically virulent human viruses in the world and a lot of research has been conducted on the first two, they are relatively new and thus there are several unanswered questions. For instance, the relationship between CoVs and EVs is still unclear and barely explored. In this respect, studies carried out on viral proteins and replicative strategies of these viruses suggest that CoVs hijack the vesicular release pathway in some way. It is possible to speculate that CoVs could influence EV release and composition (see Figure 4). Several research groups reported that coronavirus replication is strictly linked to intracellular vesicle 
formation, and the replicative complex binds the intracellular membrane, leading to the formation of vesicular structures. Two different vesicular structures have been identified: the first one corresponds to single-membrane spherules that are formed in membranous organelles, such as ER, peroxisomes or endosomes [152]; the second ones are double-membrane vesicles (DMVs) with a diameter of about 200-300 nm, which are often associated to other structures, such as tubules or ER membranes, thus forming a vesicular network in the cytosol [153-158]. The generation process of these structures is still not fully understood. Some research groups suggested that DMV formation could be correlated with the viral hijacking of the host's autophagy machinery $[159,160]$. However, it is a common idea that different viral Nsps, thanks to their transmembrane domains and the fact that they are anchored to the membrane, can promote the formation of these structures. Interestingly, Nsp3, Nsp4 and Nsp6 SARS proteins are able to induce the formation of bilayer membrane vesicles in tissue cultures. Indeed, both the exogenous treatment with Nsp3 protein and the endogenous expression of Nsp3, Nsp4 and Nsp6 proteins may perturb the membrane network [161,162]. Moreover, the co-transfection of constructs for the expression of the three Nsps prompts the budding of vesicles in target cells. The phenotype obtained was very similar to the one observed during viral infection [161].

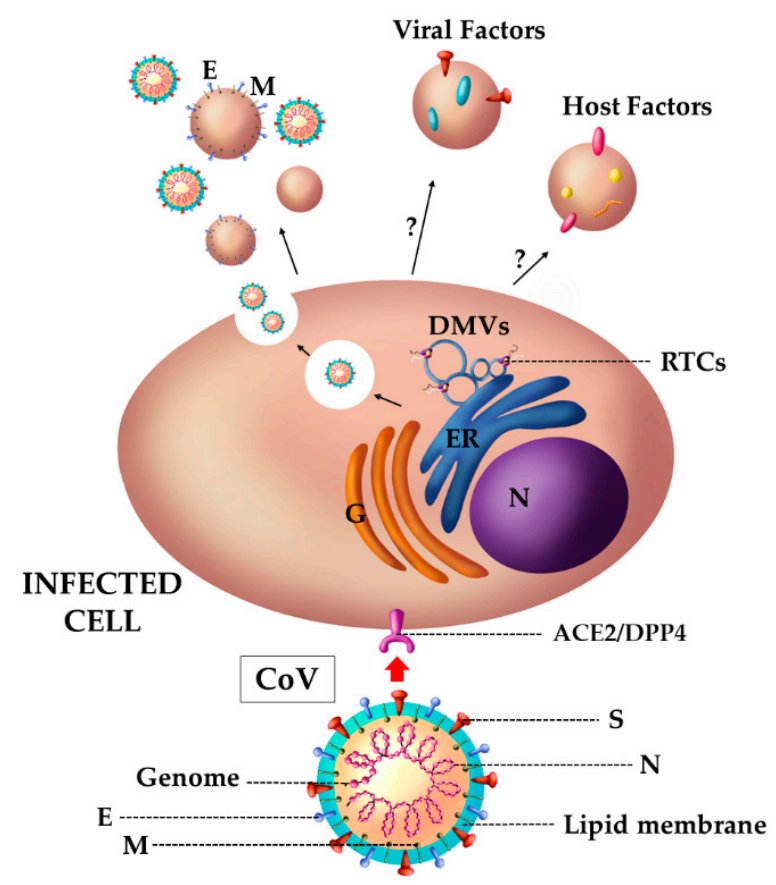

Figure 4. Schematic representation of EVs released by coronavirus (CoV)-infected cells. CoVs hijack the cellular machinery to favor their replication. CoVs proteins promote the formation into the cytosol of double-membrane vesicles (DMVs) that are associated to the replication and transcription complexes (RTCs) where the viral replication occurs. After the production of structural and non-structural proteins, the budding can take place from Golgi and ER membranes. Subsequently, viral particles are released into the extracellular space by exploiting the vesicular network. In addition to viral particles, CoVs induce the release of vesicles carrying the viral envelope $(\mathrm{E})$ and membrane $(\mathrm{M})$ proteins. To date, there are not clear evidences of vesicles released by $\mathrm{CoV}$-infected cells transporting other viral or host factors. Nucleus (N); endoplasmic reticulum (ER); Golgi complex (G).

Other $\mathrm{CoV}$ proteins are involved in membrane morphological modifications. For instance, the S2 subunit of the spike glycoprotein, which is involved in the cellular attachment, possesses various membranotropic segments that induce membrane perturbation and could allow membrane negative curvature [163]. Additionally, it was reported that $\mathrm{M}$ and $\mathrm{E}$ glycoproteins can promote, by themselves, the formation and release of $100 \mathrm{~nm}$ "vesicles", morphologically indistinguishable from viral particles. These data confirm the possibility of the production of nucleocapsidless particles during 
CoV infection [164]. As reported for other viruses, the production of vesicles together with the viral progeny could be a useful strategy to mask viral particles and transport viral factors to uninfected cells. In conclusion, these observations suggest that $\mathrm{CoVs}$, like other viruses, exploit the cellular pathways to produce EVs, even if, to date, there is no clear evidence of their induction during $\mathrm{CoV}$ infection in vivo.

\section{New Therapeutic and Vaccination Strategies Using Extracellular Vesicles}

EVs are not only vehicles that can promote viral progression and pathogenesis, but are also important immunostimulatory structures acting as mediators of immune responses. In this regard, it was found that vesicles from dendritic cells (DCs), carrying the major histocompatibility complexes MHC-I and -II, as well as costimulatory molecules such as CD80 and CD86, can induce CD8 ${ }^{+}$and CD4 ${ }^{+}$ T lymphocyte activation [165]. Different groups have explored how EVs modulate the immune system in various pathological conditions [34,166]. In the context of infections, for instance, the transport of viral components can make EVs a double-edged sword: on the one hand, they support viral spreading and pathogenesis, while, on the other hand, they can potentially transfer viral antigens to immune cells and be responsible for the induction of adaptive immunity that is able to counteract the viral spreading [167].

Furthermore, EVs released from infected cells can be charged with cellular proteins that have potent antiviral activities. This is the case of APOBEC3G, a cytidine deaminase that has an important role in restricting HIV replication. In infected cells, APOBEC3G is counteracted by the expression of the viral accessory protein Vif. The latter mediates the polyubiquitination and rapid proteasomal degradation of $A B O B E C 3 G$, thus preventing its incorporation into the progeny virus nucleocapsid. Uninfected cells can transport APOBEC3G through EVs to infected cells, in which it deaminates deoxycytidines in the minus-DNA strand that is formed during reverse transcription. This results in a high rate of nucleotide base substitutions (G-to-A transition) or the premature termination of reverse transcription that is incompatible with viral viability [168]. Additionally, vesicles released by HSV-1-infected cells transport molecules of the innate immune system such as the stimulator of interferon genes (STING), which establishes an antiviral response in target cells [169].

The growing body of evidence indicating the capability of EVs to promote an immune response increased interest in the use of vesicles as potential therapeutic or diagnostic tools. In this regard, EVs are considered excellent biomarker candidates that hold great potential for the detection of many pathological conditions, due to their ability to alter their cargo according to different cell stimuli. Moreover, since EVs are present in many biological fluids, they are easily accessible for liquid biopsy [170]. Another aspect that has gained considerable interest in the scientific community is the potential use of EVs as drug delivery vehicles. In fact, EVs offer distinct advantages as gene therapy delivery vectors since they possess cellular membranes with multiple adhesive proteins on their surface. Their small size and flexibility enable them to cross major biological barriers, such as the blood-brain barrier. Their potential utility in drug delivery is also due to their intrinsic homing capacity. Unlike liposome formulations and lentiviral-based delivery systems, EVs are naturally secreted by cells and thus they possess a high biocompatibility, safety and stability in circulation, which allow them to overcome many of the limitations of cell-based therapeutics. In this regard, it was demonstrated that EVs are able to deliver the anti-inflammatory agent curcumin that, in this form, was found to be more stable than free curcumin [171].

To date, some studies have used EVs-based therapeutics to treat diseases by engineering EVs with full-length proteins that were effective in inducing specific, unrestricted cytotoxic T cell (CTL) immunity when injected in mice. Specifically, they use a DNA vector for the expression of HIV-1 Nefmut peptide fused with human papillomavirus E7 viral antigen. Nefmut peptide allows the anchoring of the antigen to EV membranes and increases the production of vesicles in target cells. The intramuscular injection of the vector prompts the spontaneous production of EVs charged with the foreign protein fused to Nefmut, which appears to induce an important immunological response [172]. Subsequently, the same group explored the possibility to use this vesicle-based vaccine platform with different viral antigens 
such as Ebola virus VP24, VP40 and NP, Influenza virus NP, HCV NS3 and others. All the antigens tested were detected in engineered EVs that triggered the expected immunological response [173]. Another research group has proposed the engineering of the SARS-CoV S protein with VSV-G protein to generate an expressing vector for a chimeric receptor protein, because the $S$ wild type protein of SARS was not detected in vesicles isolated from transfected HEK293 cells. Through transfection procedures, they obtained a cell population expressing the fusion protein and producing EVs charged with the $\mathrm{S}$ chimeric protein. When engineered EVs were injected in mice, the induction of high levels of neutralizing antibodies was observed [174].

In conclusion, EVs appear to be promising bio-nanoparticles for the development of new therapeutic, diagnostic and prophylaxis strategies against microbial infections and other pathologies. This emerging field has a good chance to provide relevant results for the treatment of different viral infections.

\section{Conclusions}

EVs are important mediators of cell-to-cell communication both in physiological and pathological conditions. Their importance is due to EVs' capacity to transport different biological molecules such as lipids, proteins, or nucleic acids to target cells, where they can promote a wide range of effects. Many studies have suggested that EVs and viruses are not so distant as one might imagine and, in some respects, they seem to be close relatives. During infections, many viruses take advantage of EVs by hijacking their vesicular biogenesis machinery; they modify EVs by incorporating specific viral factors that contribute to create a suitable environment for viral infection. HIV, HCV and SARS viruses are three representative examples of how viruses, in different ways, can exploit EV production to favor their survival and diffusion. As reported in this review, different structural proteins such as Gag and gp120 for HIV, the proteins E1 and E2 for HCV, and the proteins E and M for coronaviruses, have been detected inside EVs, probably as a consequence of their involvement in viral budding $[106,107,115,164]$. The generation of vesicles like viral particles during the infection could be a helpful strategy for the virus to avoid recognition by the immune system. Moreover, EVs can transport non-structural proteins and other viral factors, such as Nef [93-98] and/or the TAR RNA of HIV [109,110], or even the entire viral genome as in the case of HCV [116]. Both HIV and HCV are able to hijack the cellular system by redirecting cellular proteins and nucleic acids into EVs to create an appropriate environment for their own replication and spread. For example, HIV-EVs transport the viral co-receptors CCR5 and CXCR4 to other cells to extend the pool of target cells available for the virus [88,89], and the metalloprotease ADAM17, which is involved in the inflammatory response $[99,100]$, whereas HCV-EVs are charged with Ago2 and miRNAs [111,112,119,120]. The delivery of cellular and viral proteins through EVs exerts multiple effects on target cells. HIV-TAR RNA, for example, produces microRNAs with anti-apoptotic effects, helping the survival of infected cells [110], whereas HIV-Nef EVs and HCV-Ago2-miRNA122 EVs act in target cells by enhancing viral replication. Moreover, HIV-EVs containing Nef, ADAM17 or TAR RNA and HCV-EVs with miRNA-192 and miRNA-19a have been associated to the perturbation of the cytokine/chemokine network [101-105,111,112,120]. Many of these effects allow the preservation of cell activation, thus favoring viral entry and replication, and often contributing to the progression of the pathogenesis. To date, few in-depth studies concerning vesicles and coronaviruses have been reported in the literature, since these viruses have only recently attracted the interest of the scientific community. Therefore, this field is certainly open to new studies and coronaviruses could significantly affect EV content. Finally, viral EVs not only help pathogens, but they are also recognized and used by the host to induce innate and adaptive immune responses to viral infections. Ongoing research will pave the way for therapeutic and/or prophylaxis strategies that exploit EVs.

Author Contributions: E.A. conceived the topic of the review. F.G., A.A., and F.F. equally contributed to drafting the original manuscript. E.A. and Z.A.P. revised and edited the final manuscript. All authors have read and agreed to the published version of the manuscript. 
Funding: This work was supported by the grant "Excellence Departments, MIUR-Italy (ARTICOLO 1, COMMI 314-337 LEGGE 232/2016)".

Conflicts of Interest: The authors declare no conflict of interest. The funders had no role in the design of the study; in the collection, analyses, or interpretation of data; in the writing of the manuscript, or in the decision to publish the results.

\section{References}

1. Raposo, G.; Stoorvogel, W. Extracellular vesicles: Exosomes, microvesicles, and friends. J. Cell Biol. 2013, 200, 373-383. [CrossRef]

2. Altan-Bonnet, N. Extracellular vesicles are the Trojan horses of viral infection. Curr. Opin. Microbiol. 2016, 32, 77-81. [CrossRef]

3. Pisitkun, T.; Shen, R.-F.; Knepper, M.A. Identification and proteomic profiling of exosomes in human urine. Proc. Natl. Acad. Sci. USA 2004, 101, 13368-13373. [CrossRef]

4. Keller, S.; Ridinger, J.; Rupp, A.-K.; Janssen, J.W.G.; Altevogt, P. Body fluid derived exosomes as a novel template for clinical diagnostics. J. Transl. Med. 2011, 9, 86. [CrossRef]

5. Caby, M.-P.; Lankar, D.; Vincendeau-Scherrer, C.; Raposo, G.; Bonnerot, C. Exosomal-like vesicles are present in human blood plasma. Int. Immunol. 2005, 17, 879-887. [CrossRef]

6. Poliakov, A.; Spilman, M.; Dokland, T.; Amling, C.L.; Mobley, J.A. Structural heterogeneity and protein composition of exosome-like vesicles (prostasomes) in human semen. Prostate 2009, 69, 159-167. [CrossRef] [PubMed]

7. Lässer, C.; O’Neil, S.E.; Ekerljung, L.; Ekström, K.; Sjöstrand, M.; Lötvall, J. RNA-containing exosomes in human nasal secretions. Am. J. Rhinol. Allergy 2011, 25, 89-93. [CrossRef] [PubMed]

8. Raposo, G.; Nijman, H.W.; Stoorvogel, W.; Liejendekker, R.; Harding, C.V.; Melief, C.J.; Geuze, H.J. B lymphocytes secrete antigen-presenting vesicles. J. Exp. Med. 1996, 183, 1161-1172. [CrossRef] [PubMed]

9. Fauré, J.; Lachenal, G.; Court, M.; Hirrlinger, J.; Chatellard-Causse, C.; Blot, B.; Grange, J.; Schoehn, G.; Goldberg, Y.; Boyer, V.; et al. Exosomes are released by cultured cortical neurones. Mol. Cell. Neurosci. 2006, 31, 642-648. [CrossRef]

10. Berckmans, R.J.; Sturk, A.; van Tienen, L.M.; Schaap, M.C.L.; Nieuwland, R. Cell-derived vesicles exposing coagulant tissue factor in saliva. Blood 2011, 117, 3172-3180. [CrossRef]

11. Biró, E.; Sturk-Maquelin, K.N.; Vogel, G.M.T.; Meuleman, D.G.; Smit, M.J.; Hack, C.E.; Sturk, A.; Nieuwland, R. Human cell-derived microparticles promote thrombus formation in vivo in a tissue factor-dependent manner. J. Thromb. Haemost. 2003, 1, 2561-2568. [CrossRef] [PubMed]

12. Sullivan, R.; Saez, F.; Girouard, J.; Frenette, G. Role of exosomes in sperm maturation during the transit along the male reproductive tract. Blood Cells Mol. Dis. 2005, 35, 1-10. [CrossRef] [PubMed]

13. Stefanski, A.L.; Martinez, N.; Peterson, L.K.; Callahan, T.J.; Treacy, E.; Luck, M.; Friend, S.F.; Hermesch, A.; Maltepe, E.; Phang, T.; et al. Murine trophoblast-derived and pregnancy-associated exosome-enriched extracellular vesicle microRNAs: Implications for placenta driven effects on maternal physiology. PLoS ONE 2019, 14, e0210675. [CrossRef] [PubMed]

14. Hanahan, D.; Weinberg, R.A. Hallmarks of cancer: The next generation. Cell 2011, 144, 646-674. [CrossRef] [PubMed]

15. Buzas, E.I.; György, B.; Nagy, G.; Falus, A.; Gay, S. Emerging role of extracellular vesicles in inflammatory diseases. Nat. Rev. Rheumatol. 2014, 10, 356-364. [CrossRef]

16. Silverman, J.M.; Reiner, N.E. Exosomes and other microvesicles in infection biology: Organelles with unanticipated phenotypes. Cell. Microbiol. 2011, 13, 1-9. [CrossRef]

17. Schwab, A.; Meyering, S.S.; Lepene, B.; Iordanskiy, S.; van Hoek, M.L.; Hakami, R.M.; Kashanchi, F. Extracellular vesicles from infected cells: Potential for direct pathogenesis. Front. Microbiol. 2015, 6, 1132. [CrossRef]

18. Colombo, M.; Raposo, G.; Théry, C. Biogenesis, secretion, and intercellular interactions of exosomes and other extracellular vesicles. Annu. Rev. Cell Dev. Biol. 2014, 30, 255-289. [CrossRef]

19. van Niel, G.; D'Angelo, G.; Raposo, G. Shedding light on the cell biology of extracellular vesicles. Nat. Rev. Mol. Cell Biol. 2018, 19, 213-228. [CrossRef] 
20. Caruso, S.; Poon, I.K.H. Apoptotic Cell-Derived Extracellular Vesicles: More Than Just Debris. Front. Immunol. 2018, 9, 1486. [CrossRef]

21. Schorey, J.S.; Bhatnagar, S. Exosome function: From tumor immunology to pathogen biology. Traffic 2008, 9, 871-881. [CrossRef] [PubMed]

22. D'Souza-Schorey, C.; Schorey, J.S. Regulation and mechanisms of extracellular vesicle biogenesis and secretion. Essays Biochem. 2018, 62, 125-133. [CrossRef] [PubMed]

23. Urbanelli, L.; Buratta, S.; Tancini, B.; Sagini, K.; Delo, F.; Porcellati, S.; Emiliani, C. The Role of Extracellular Vesicles in Viral Infection and Transmission. Vaccines (Basel) 2019, 7, 102. [CrossRef]

24. Dias, M.V.S.; Costa, C.S.; daSilva, L.L.P. The Ambiguous Roles of Extracellular Vesicles in HIV Replication and Pathogenesis. Front. Microbiol. 2018, 9, 2411. [CrossRef] [PubMed]

25. Dreyer, F.; Baur, A. Biogenesis and Functions of Exosomes and Extracellular Vesicles. Methods Mol. Biol. 2016, 1448, 201-216. [CrossRef] [PubMed]

26. Shurer, C.R.; Kuo, J.C.-H.; Roberts, L.M.; Gandhi, J.G.; Colville, M.J.; Enoki, T.A.; Pan, H.; Su, J.; Noble, J.M.; Hollander, M.J.; et al. Physical Principles of Membrane Shape Regulation by the Glycocalyx. Cell 2019, 177, 1757-1770. [CrossRef]

27. Cloosen, S.; Thio, M.; Vanclée, A.; van Leeuwen, E.B.M.; Senden-Gijsbers, B.L.M.G.; Oving, E.B.H.; Germeraad, W.T.V.; Bos, G.M.J. Mucin-1 is expressed on dendritic cells, both in vitro and in vivo. Int. Immunol. 2004, 16, 1561-1571. [CrossRef]

28. Gangoda, L.; Boukouris, S.; Liem, M.; Kalra, H.; Mathivanan, S. Extracellular vesicles including exosomes are mediators of signal transduction: Are they protective or pathogenic? Proteomics 2015, 15, 260-271. [CrossRef]

29. McConnell, R.E.; Higginbotham, J.N.; Shifrin, D.A.; Tabb, D.L.; Coffey, R.J.; Tyska, M.J. The enterocyte microvillus is a vesicle-generating organelle. J. Cell Biol. 2009, 185, 1285-1298. [CrossRef]

30. Paszek, M.J.; DuFort, C.C.; Rossier, O.; Bainer, R.; Mouw, J.K.; Godula, K.; Hudak, J.E.; Lakins, J.N.; Wijekoon, A.C.; Cassereau, L.; et al. The cancer glycocalyx mechanically primes integrin-mediated growth and survival. Nature 2014, 511, 319-325. [CrossRef]

31. Pelaseyed, T.; Bergström, J.H.; Gustafsson, J.K.; Ermund, A.; Birchenough, G.M.H.; Schütte, A.; van der Post, S.; Svensson, F.; Rodríguez-Piñeiro, A.M.; Nyström, E.E.L.; et al. The mucus and mucins of the goblet cells and enterocytes provide the first defense line of the gastrointestinal tract and interact with the immune system. Immunol. Rev. 2014, 260, 8-20. [CrossRef] [PubMed]

32. Tricarico, C.; Clancy, J.; D'Souza-Schorey, C. Biology and biogenesis of shed microvesicles. Small GTPases 2017, 8, 220-232. [CrossRef] [PubMed]

33. Raab-Traub, N.; Dittmer, D.P. Viral effects on the content and function of extracellular vesicles. Nat. Rev. Microbiol. 2017, 15, 559-572. [CrossRef] [PubMed]

34. Schorey, J.S.; Cheng, Y.; Singh, P.P.; Smith, V.L. Exosomes and other extracellular vesicles in host-pathogen interactions. EMBO Rep. 2015, 16, 24-43. [CrossRef] [PubMed]

35. Valadi, H.; Ekström, K.; Bossios, A.; Sjöstrand, M.; Lee, J.J.; Lötvall, J.O. Exosome-mediated transfer of mRNAs and microRNAs is a novel mechanism of genetic exchange between cells. Nat. Cell Biol. 2007, 9, 654-659. [CrossRef]

36. Aiello, A.; Giannessi, F.; Percario, Z.A.; Affabris, E. An emerging interplay between extracellular vesicles and cytokines. Cytokine Growth Factor Rev. 2020, 51, 49-60. [CrossRef]

37. Nolte-'t Hoen, E.N.M.; Buermans, H.P.J.; Waasdorp, M.; Stoorvogel, W.; Wauben, M.H.M.; 't Hoen, P.A.C. Deep sequencing of RNA from immune cell-derived vesicles uncovers the selective incorporation of small non-coding RNA biotypes with potential regulatory functions. Nucleic Acids Res. 2012, 40, 9272-9285. [CrossRef]

38. Vojtech, L.; Woo, S.; Hughes, S.; Levy, C.; Ballweber, L.; Sauteraud, R.P.; Strobl, J.; Westerberg, K.; Gottardo, R.; Tewari, M.; et al. Exosomes in human semen carry a distinctive repertoire of small non-coding RNAs with potential regulatory functions. Nucleic Acids Res. 2014, 42, 7290-7304. [CrossRef]

39. Morita, E.; Sundquist, W.I. Retrovirus budding. Annu. Rev. Cell Dev. Biol. 2004, 20, 395-425. [CrossRef]

40. Bieniasz, P.D. Late budding domains and host proteins in enveloped virus release. Virology 2006, 344, 55-63. [CrossRef]

41. Nguyen, D.H.; Hildreth, J.E. Evidence for budding of human immunodeficiency virus type 1 selectively from glycolipid-enriched membrane lipid rafts. J. Virol. 2000, 74, 3264-3272. [CrossRef] [PubMed] 
42. Trajkovic, K.; Hsu, C.; Chiantia, S.; Rajendran, L.; Wenzel, D.; Wieland, F.; Schwille, P.; Brügger, B.; Simons, M. Ceramide triggers budding of exosome vesicles into multivesicular endosomes. Science 2008, 319, 1244-1247. [CrossRef] [PubMed]

43. Le Mercier, P.; Mariethoz, J.; Lascano-Maillard, J.; Bonnardel, F.; Imberty, A.; Ricard-Blum, S.; Lisacek, F. A Bioinformatics View of Glycan-Virus Interactions. Viruses 2019, 11, 374. [CrossRef] [PubMed]

44. Böhm, R.; Fleming, F.E.; Maggioni, A.; Dang, V.T.; Holloway, G.; Coulson, B.S.; von Itzstein, M.; Haselhorst, T. Revisiting the role of histo-blood group antigens in rotavirus host-cell invasion. Nat. Commun. 2015, 6, 5907. [CrossRef] [PubMed]

45. da Silva, R.C.; Segat, L.; Crovella, S. Role of DC-SIGN and L-SIGN receptors in HIV-1 vertical transmission. Hum. Immunol. 2011, 72, 305-311. [CrossRef] [PubMed]

46. Simmons, G.; Reeves, J.D.; Grogan, C.C.; Vandenberghe, L.H.; Baribaud, F.; Whitbeck, J.C.; Burke, E.; Buchmeier, M.J.; Soilleux, E.J.; Riley, J.L.; et al. DC-SIGN and DC-SIGNR bind ebola glycoproteins and enhance infection of macrophages and endothelial cells. Virology 2003, 305, 115-123. [CrossRef]

47. Lai, W.K.; Sun, P.J.; Zhang, J.; Jennings, A.; Lalor, P.F.; Hubscher, S.; McKeating, J.A.; Adams, D.H. Expression of DC-SIGN and DC-SIGNR on Human Sinusoidal Endothelium. Am. J. Pathol. 2006, 169, 200-208. [CrossRef]

48. Londrigan, S.L.; Turville, S.G.; Tate, M.D.; Deng, Y.-M.; Brooks, A.G.; Reading, P.C. N-linked glycosylation facilitates sialic acid-independent attachment and entry of influenza A viruses into cells expressing DC-SIGN or L-SIGN. J. Virol. 2011, 85, 2990-3000. [CrossRef]

49. Yang, Z.-Y.; Huang, Y.; Ganesh, L.; Leung, K.; Kong, W.-P.; Schwartz, O.; Subbarao, K.; Nabel, G.J. $\mathrm{pH}$-dependent entry of severe acute respiratory syndrome coronavirus is mediated by the spike glycoprotein and enhanced by dendritic cell transfer through DC-SIGN. J. Virol. 2004, 78, 5642-5650. [CrossRef]

50. Bonomelli, C.; Doores, K.J.; Dunlop, D.C.; Thaney, V.; Dwek, R.A.; Burton, D.R.; Crispin, M.; Scanlan, C.N. The glycan shield of HIV is predominantly oligomannose independently of production system or viral clade. PLoS ONE 2011, 6, e23521. [CrossRef]

51. Watanabe, Y.; Raghwani, J.; Allen, J.D.; Seabright, G.E.; Li, S.; Moser, F.; Huiskonen, J.T.; Strecker, T.; Bowden, T.A.; Crispin, M. Structure of the Lassa virus glycan shield provides a model for immunological resistance. Proc. Natl. Acad. Sci. USA 2018, 115, 7320-7325. [CrossRef]

52. Segura, E.; Nicco, C.; Lombard, B.; Véron, P.; Raposo, G.; Batteux, F.; Amigorena, S.; Théry, C. ICAM-1 on exosomes from mature dendritic cells is critical for efficient naive T-cell priming. Blood 2005, 106, 216-223. [CrossRef] [PubMed]

53. Gould, S.J.; Booth, A.M.; Hildreth, J.E.K. The Trojan exosome hypothesis. Proc. Natl. Acad. Sci. USA 2003, 100, 10592-10597. [CrossRef] [PubMed]

54. Pelchen-Matthews, A.; Raposo, G.; Marsh, M. Endosomes, exosomes and Trojan viruses. Trends Microbiol. 2004, 12, 310-316. [CrossRef] [PubMed]

55. Izquierdo-Useros, N.; Puertas, M.C.; Borràs, F.E.; Blanco, J.; Martinez-Picado, J. Exosomes and retroviruses: The chicken or the egg? Cell. Microbiol. 2011, 13, 10-17. [CrossRef] [PubMed]

56. Eckner, R.J.; Hettrick, K.L. Defective Friend Spleen Focus-Forming Virus: Interfering Properties and Isolation Free from Standard Leukemia-Inducing Helper Virus. J. Virol. 1977, 24, 383-396. [CrossRef] [PubMed]

57. Théry, C.; Witwer, K.W.; Aikawa, E.; Alcaraz, M.J.; Anderson, J.D.; Andriantsitohaina, R.; Antoniou, A.; Arab, T.; Archer, F.; Atkin-Smith, G.K.; et al. Minimal information for studies of extracellular vesicles 2018 (MISEV2018): A position statement of the International Society for Extracellular Vesicles and update of the MISEV2014 guidelines. J. Extracell. Vesicles 2018, 7, 1535750. [CrossRef]

58. Cantin, R.; Diou, J.; Bélanger, D.; Tremblay, A.M.; Gilbert, C. Discrimination between exosomes and HIV-1: Purification of both vesicles from cell-free supernatants. J. Immunol. Methods 2008, 338, 21-30. [CrossRef]

59. Konadu, K.A.; Huang, M.B.; Roth, W.; Armstrong, W.; Powell, M.; Villinger, F.; Bond, V. Isolation of Exosomes from the Plasma of HIV-1 Positive Individuals. J. Vis. Exp. 2016, 107, e53495. [CrossRef]

60. Théry, C.; Ostrowski, M.; Segura, E. Membrane vesicles as conveyors of immune responses. Nat. Rev. Immunol. 2009, 9, 581-593. [CrossRef]

61. Feng, Z.; Hensley, L.; McKnight, K.L.; Hu, F.; Madden, V.; Ping, L.; Jeong, S.-H.; Walker, C.; Lanford, R.E.; Lemon, S.M. A pathogenic picornavirus acquires an envelope by hijacking cellular membranes. Nature 2013, 496, 367-371. [CrossRef]

62. Inal, J.M.; Jorfi, S. Coxsackievirus B transmission and possible new roles for extracellular vesicles. Biochem. Soc. Trans. 2013, 41, 299-302. [CrossRef] 
63. Mao, L.; Wu, J.; Shen, L.; Yang, J.; Chen, J.; Xu, H. Enterovirus 71 transmission by exosomes establishes a productive infection in human neuroblastoma cells. Virus Genes 2016, 52, 189-194. [CrossRef] [PubMed]

64. Hirai-Yuki, A.; Hensley, L.; Whitmire, J.K.; Lemon, S.M. Biliary Secretion of Quasi-Enveloped Human Hepatitis A Virus. mBio 2016, 7, e01998-16. [CrossRef] [PubMed]

65. Chen, Y.-H.; Du, W.; Hagemeijer, M.C.; Takvorian, P.M.; Pau, C.; Cali, A.; Brantner, C.A.; Stempinski, E.S.; Connelly, P.S.; Ma, H.-C.; et al. Phosphatidylserine vesicles enable efficient en bloc transmission of multiple enteroviruses. Cell 2015, 160, 619-630. [CrossRef] [PubMed]

66. Nolte't Hoen, E.; Cremer, T.; Gallo, R.C.; Margolis, L.B. Extracellular vesicles and viruses: Are they close relatives? Proc. Natl. Acad. Sci. USA 2016, 113, 9155-9161. [CrossRef] [PubMed]

67. Houali, K.; Wang, X.; Shimizu, Y.; Djennaoui, D.; Nicholls, J.; Fiorini, S.; Bouguermouh, A.; Ooka, T. A new diagnostic marker for secreted Epstein-Barr virus encoded LMP1 and BARF1 oncoproteins in the serum and saliva of patients with nasopharyngeal carcinoma. Clin. Cancer Res. 2007, 13, 4993-5000. [CrossRef]

68. Flanagan, J.; Middeldorp, J.; Sculley, T. Localization of the Epstein-Barr virus protein LMP 1 to exosomes. J. Gen. Virol. 2003, 84, 1871-1879. [CrossRef] [PubMed]

69. Kieser, A.; Sterz, K.R. The Latent Membrane Protein 1 (LMP1). Curr. Top. Microbiol. Immunol. 2015, 391, 119-149. [CrossRef]

70. Meckes, D.G.; Shair, K.H.Y.; Marquitz, A.R.; Kung, C.-P.; Edwards, R.H.; Raab-Traub, N. Human tumor virus utilizes exosomes for intercellular communication. Proc. Natl. Acad. Sci. USA 2010, 107, 20370-20375. [CrossRef]

71. Hurwitz, S.N.; Nkosi, D.; Conlon, M.M.; York, S.B.; Liu, X.; Tremblay, D.C.; Meckes, D.G. CD63 Regulates Epstein-Barr Virus LMP1 Exosomal Packaging, Enhancement of Vesicle Production, and Noncanonical NF-кB Signaling. J. Virol. 2017, 91, e02251-16. [CrossRef] [PubMed]

72. Verweij, F.J.; van Eijndhoven, M.A.J.; Hopmans, E.S.; Vendrig, T.; Wurdinger, T.; Cahir-McFarland, E.; Kieff, E.; Geerts, D.; van der Kant, R.; Neefjes, J.; et al. LMP1 association with CD63 in endosomes and secretion via exosomes limits constitutive NF-kB activation. EMBO J. 2011, 30, 2115-2129. [CrossRef] [PubMed]

73. Ardila-Osorio, H.; Pioche-Durieu, C.; Puvion-Dutilleul, F.; Clausse, B.; Wiels, J.; Miller, W.; Raab-Traub, N.; Busson, P. TRAF interactions with raft-like buoyant complexes, better than TRAF rates of degradation, differentiate signaling by CD40 and EBV latent membrane protein 1. Int. J. Cancer 2005, 113, 267-275. [CrossRef] [PubMed]

74. Dukers, D.F.; Meij, P.; Vervoort, M.B.; Vos, W.; Scheper, R.J.; Meijer, C.J.; Bloemena, E.; Middeldorp, J.M. Direct immunosuppressive effects of EBV-encoded latent membrane protein 1. J. Immunol. 2000, 165, 663-670. [CrossRef]

75. Nanbo, A.; Kawanishi, E.; Yoshida, R.; Yoshiyama, H. Exosomes derived from Epstein-Barr virus-infected cells are internalized via caveola-dependent endocytosis and promote phenotypic modulation in target cells. J. Virol. 2013, 87, 10334-10347. [CrossRef]

76. Verweij, F.J.; van Eijndhoven, M.A.J.; Middeldorp, J.; Pegtel, D.M. Analysis of viral microRNA exchange via exosomes in vitro and in vivo. Methods Mol. Biol. 2013, 1024, 53-68. [CrossRef]

77. Zhao, M.; Nanbo, A.; Sun, L.; Lin, Z. Extracellular Vesicles in Epstein-Barr Virus' Life Cycle and Pathogenesis. Microorganisms 2019, 7, 48. [CrossRef]

78. Choi, H.; Lee, H.; Kim, S.R.; Gho, Y.S.; Lee, S.K. Epstein-Barr virus-encoded microRNA BART15-3p promotes cell apoptosis partially by targeting BRUCE. J. Virol. 2013, 87, 8135-8144. [CrossRef]

79. Gallo, A.; Vella, S.; Miele, M.; Timoneri, F.; Di Bella, M.; Bosi, S.; Sciveres, M.; Conaldi, P.G. Global profiling of viral and cellular non-coding RNAs in Epstein-Barr virus-induced lymphoblastoid cell lines and released exosome cargos. Cancer Lett. 2017, 388, 334-343. [CrossRef] [PubMed]

80. Ahmed, W.; Philip, P.S.; Tariq, S.; Khan, G. Epstein-Barr virus-encoded small RNAs (EBERs) are present in fractions related to exosomes released by EBV-transformed cells. PLoS ONE 2014, 9, e99163. [CrossRef] [PubMed]

81. Meckes, D.G.; Gunawardena, H.P.; Dekroon, R.M.; Heaton, P.R.; Edwards, R.H.; Ozgur, S.; Griffith, J.D.; Damania, B.; Raab-Traub, N. Modulation of B-cell exosome proteins by gamma herpesvirus infection. Proc. Natl. Acad. Sci. USA 2013, 110, E2925-E2933. [CrossRef] [PubMed]

82. Singh, V.V.; Kerur, N.; Bottero, V.; Dutta, S.; Chakraborty, S.; Ansari, M.A.; Paudel, N.; Chikoti, L.; Chandran, B. Kaposi's Sarcoma-Associated Herpesvirus Latency in Endothelial and B Cells Activates Gamma Interferon-Inducible Protein 16-Mediated Inflammasomes. J. Virol. 2013, 87, 4417-4431. [CrossRef] [PubMed] 
83. Plazolles, N.; Humbert, J.-M.; Vachot, L.; Verrier, B.; Hocke, C.; Halary, F. Pivotal advance: The promotion of soluble DC-SIGN release by inflammatory signals and its enhancement of cytomegalovirus-mediated cis-infection of myeloid dendritic cells. J. Leukoc. Biol. 2011, 89, 329-342. [CrossRef] [PubMed]

84. Temme, S.; Eis-Hübinger, A.M.; McLellan, A.D.; Koch, N. The herpes simplex virus-1 encoded glycoprotein B diverts HLA-DR into the exosome pathway. J. Immunol. 2010, 184, 236-243. [CrossRef]

85. Kalamvoki, M.; Du, T.; Roizman, B. Cells infected with herpes simplex virus 1 export to uninfected cells exosomes containing STING, viral mRNAs, and microRNAs. Proc. Natl. Acad. Sci. USA 2014, 111, E4991-E4996. [CrossRef]

86. Fanales-Belasio, E.; Raimondo, M.; Suligoi, B.; Buttò, S. HIV virology and pathogenetic mechanisms of infection: A brief overview. Annali Istituto Superiore Sanita 2010, 46, 5-14. [CrossRef]

87. Percario, Z.A.; Ali, M.; Mangino, G.; Affabris, E. Nef, the shuttling molecular adaptor of HIV, influences the cytokine network. Cytokine Growth Factor Rev. 2015, 26, 159-173. [CrossRef]

88. Mack, M.; Kleinschmidt, A.; Brühl, H.; Klier, C.; Nelson, P.J.; Cihak, J.; Plachý, J.; Stangassinger, M.; Erfle, V.; Schlöndorff, D. Transfer of the chemokine receptor CCR5 between cells by membrane-derived microparticles: A mechanism for cellular human immunodeficiency virus 1 infection. Nat. Med. 2000, 6, 769-775. [CrossRef]

89. Rozmyslowicz, T.; Majka, M.; Kijowski, J.; Murphy, S.L.; Conover, D.O.; Poncz, M.; Ratajczak, J.; Gaulton, G.N.; Ratajczak, M.Z. Platelet- and megakaryocyte-derived microparticles transfer CXCR4 receptor to CXCR4-null cells and make them susceptible to infection by X4-HIV. AIDS 2003, 17, 33-42. [CrossRef]

90. Rosa, A.; Chande, A.; Ziglio, S.; De Sanctis, V.; Bertorelli, R.; Goh, S.L.; McCauley, S.M.; Nowosielska, A.; Antonarakis, S.E.; Luban, J.; et al. HIV-1 Nef promotes infection by excluding SERINC5 from virion incorporation. Nature 2015, 526, 212-217. [CrossRef]

91. Usami, Y.; Wu, Y.; Göttlinger, H.G. SERINC3 and SERINC5 restrict HIV-1 infectivity and are counteracted by Nef. Nature 2015, 526, 218-223. [CrossRef] [PubMed]

92. Pawlak, E.N.; Dikeakos, J.D. HIV-1 Nef: A master manipulator of the membrane trafficking machinery mediating immune evasion. Biochim. Biophys. Acta 2015, 1850, 733-741. [CrossRef] [PubMed]

93. Baur, A.S. HIV-Nef and AIDS pathogenesis: Are we barking up the wrong tree? Trends Microbiol. 2011, 19, 435-440. [CrossRef] [PubMed]

94. Lenassi, M.; Cagney, G.; Liao, M.; Vaupotic, T.; Bartholomeeusen, K.; Cheng, Y.; Krogan, N.J.; Plemenitas, A.; Peterlin, B.M. HIV Nef is secreted in exosomes and triggers apoptosis in bystander CD4+ T cells. Traffic 2010, 11, 110-122. [CrossRef]

95. Muratori, C.; Cavallin, L.E.; Krätzel, K.; Tinari, A.; De Milito, A.; Fais, S.; D’Aloja, P.; Federico, M.; Vullo, V.; Fomina, A.; et al. Massive secretion by T cells is caused by HIV Nef in infected cells and by Nef transfer to bystander cells. Cell Host Microbe 2009, 6, 218-230. [CrossRef]

96. Khan, M.B.; Lang, M.J.; Huang, M.-B.; Raymond, A.; Bond, V.C.; Shiramizu, B.; Powell, M.D. Nef exosomes isolated from the plasma of individuals with HIV-associated dementia (HAD) can induce A $\beta(1-42)$ secretion in SH-SY5Y neural cells. J. Neurovirol. 2016, 22, 179-190. [CrossRef]

97. Gray, L.R.; Gabuzda, D.; Cowley, D.; Ellett, A.; Chiavaroli, L.; Wesselingh, S.L.; Churchill, M.J.; Gorry, P.R. CD4 and MHC class 1 down-modulation activities of nef alleles from brain- and lymphoid tissue-derived primary HIV-1 isolates. J. Neurovirol. 2011, 17, 82-91. [CrossRef]

98. Campbell, T.D.; Khan, M.; Huang, M.-B.; Bond, V.C.; Powell, M.D. HIV-1 Nef protein is secreted into vesicles that can fuse with target cells and virions. Ethn. Dis. 2008, 18, S2.

99. Lee, J.-H.; Schierer, S.; Blume, K.; Dindorf, J.; Wittki, S.; Xiang, W.; Ostalecki, C.; Koliha, N.; Wild, S.; Schuler, G.; et al. HIV-Nef and ADAM17-Containing Plasma Extracellular Vesicles Induce and Correlate with Immune Pathogenesis in Chronic HIV Infection. EBioMedicine 2016, 6, 103-113. [CrossRef]

100. Lee, J.-H.; Ostalecki, C.; Zhao, Z.; Kesti, T.; Bruns, H.; Simon, B.; Harrer, T.; Saksela, K.; Baur, A.S. HIV Activates the Tyrosine Kinase Hck to Secrete ADAM Protease-Containing Extracellular Vesicles. EBioMedicine 2018, 28, 151-161. [CrossRef]

101. Arenaccio, C.; Chiozzini, C.; Columba-Cabezas, S.; Manfredi, F.; Affabris, E.; Baur, A.; Federico, M. Exosomes from human immunodeficiency virus type 1 (HIV-1)-infected cells license quiescent CD4+ T lymphocytes to replicate HIV-1 through a Nef- and ADAM17-dependent mechanism. J. Virol. 2014, 88, 11529-11539. [CrossRef] [PubMed] 
102. Arenaccio, C.; Chiozzini, C.; Columba-Cabezas, S.; Manfredi, F.; Federico, M. Cell activation and HIV-1 replication in unstimulated CD4+ T lymphocytes ingesting exosomes from cells expressing defective HIV-1. Retrovirology 2014, 11, 46. [CrossRef] [PubMed]

103. Ostalecki, C.; Wittki, S.; Lee, J.-H.; Geist, M.M.; Tibroni, N.; Harrer, T.; Schuler, G.; Fackler, O.T.; Baur, A.S. HIV Nef- and Notch1-dependent Endocytosis of ADAM17 Induces Vesicular TNF Secretion in Chronic HIV Infection. EBioMedicine 2016, 13, 294-304. [CrossRef] [PubMed]

104. Arenaccio, C.; Anticoli, S.; Manfredi, F.; Chiozzini, C.; Olivetta, E.; Federico, M. Latent HIV-1 is activated by exosomes from cells infected with either replication-competent or defective HIV-1. Retrovirology 2015, $12,87$. [CrossRef]

105. Raymond, A.D.; Diaz, P.; Chevelon, S.; Agudelo, M.; Yndart-Arias, A.; Ding, H.; Kaushik, A.; Jayant, R.D.; Nikkhah-Moshaie, R.; Roy, U.; et al. Microglia-derived HIV Nef+ exosome impairment of the blood-brain barrier is treatable by nanomedicine-based delivery of Nef peptides. J. Neurovirol. 2016, 22, 129-139. [CrossRef]

106. Fang, Y.; Wu, N.; Gan, X.; Yan, W.; Morrell, J.C.; Gould, S.J. Higher-order oligomerization targets plasma membrane proteins and HIV gag to exosomes. PLoS Biol. 2007, 5, e158. [CrossRef]

107. Arakelyan, A.; Fitzgerald, W.; Zicari, S.; Vanpouille, C.; Margolis, L. Extracellular Vesicles Carry HIV Env and Facilitate Hiv Infection of Human Lymphoid Tissue. Sci. Rep. 2017, 7, 1695. [CrossRef]

108. Bernard, M.A.; Zhao, H.; Yue, S.C.; Anandaiah, A.; Koziel, H.; Tachado, S.D. Novel HIV-1 miRNAs stimulate $\mathrm{TNF} \alpha$ release in human macrophages via TLR8 signaling pathway. PLoS ONE 2014, 9, e106006. [CrossRef]

109. Narayanan, A.; Iordanskiy, S.; Das, R.; Van Duyne, R.; Santos, S.; Jaworski, E.; Guendel, I.; Sampey, G.; Dalby, E.; Iglesias-Ussel, M.; et al. Exosomes derived from HIV-1-infected cells contain trans-activation response element RNA. J. Biol. Chem. 2013, 288, 20014-20033. [CrossRef]

110. Sampey, G.C.; Saifuddin, M.; Schwab, A.; Barclay, R.; Punya, S.; Chung, M.-C.; Hakami, R.M.; Zadeh, M.A.; Lepene, B.; Klase, Z.A.; et al. Exosomes from HIV-1-infected Cells Stimulate Production of Pro-inflammatory Cytokines through Trans-activating Response (TAR) RNA. J. Biol. Chem. 2016, 291, 1251-1266. [CrossRef]

111. Devhare, P.B.; Sasaki, R.; Shrivastava, S.; Di Bisceglie, A.M.; Ray, R.; Ray, R.B. Exosome-Mediated Intercellular Communication between Hepatitis C Virus-Infected Hepatocytes and Hepatic Stellate Cells. J. Virol. 2017, 91, e02225-16. [CrossRef] [PubMed]

112. Bukong, T.N.; Momen-Heravi, F.; Kodys, K.; Bala, S.; Szabo, G. Exosomes from hepatitis C infected patients transmit HCV infection and contain replication competent viral RNA in complex with Ago2-miR122-HSP90. PLoS Pathog. 2014, 10, e1004424. [CrossRef] [PubMed]

113. Andino, R.; Domingo, E. Viral quasispecies. Virology 2015, 479-480, 46-51. [CrossRef] [PubMed]

114. Tamai, K.; Shiina, M.; Tanaka, N.; Nakano, T.; Yamamoto, A.; Kondo, Y.; Kakazu, E.; Inoue, J.; Fukushima, K.; Sano, K.; et al. Regulation of hepatitis C virus secretion by the Hrs-dependent exosomal pathway. Virology 2012, 422, 377-385. [CrossRef] [PubMed]

115. Masciopinto, F.; Giovani, C.; Campagnoli, S.; Galli-Stampino, L.; Colombatto, P.; Brunetto, M.; Yen, T.S.B.; Houghton, M.; Pileri, P.; Abrignani, S. Association of hepatitis C virus envelope proteins with exosomes. Eur. J. Immunol. 2004, 34, 2834-2842. [CrossRef]

116. Dreux, M.; Garaigorta, U.; Boyd, B.; Décembre, E.; Chung, J.; Whitten-Bauer, C.; Wieland, S.; Chisari, F.V. Short-Range Exosomal Transfer of Viral RNA from Infected Cells to Plasmacytoid Dendritic Cells Triggers Innate Immunity. Cell Host Microbe 2012, 12, 558-570. [CrossRef]

117. Ramakrishnaiah, V.; Thumann, C.; Fofana, I.; Habersetzer, F.; Pan, Q.; de Ruiter, P.E.; Willemsen, R.; Demmers, J.A.A.; Stalin Raj, V.; Jenster, G.; et al. Exosome-mediated transmission of hepatitis $C$ virus between human hepatoma Huh7.5 cells. Proc. Natl. Acad. Sci. USA 2013, 110, 13109-13113. [CrossRef]

118. Cosset, F.-L.; Dreux, M. HCV transmission by hepatic exosomes establishes a productive infection. J. Hepatol. 2014, 60, 674-675. [CrossRef]

119. Jopling, C. Liver-specific microRNA-122: Biogenesis and function. RNA Biol 2012, 9, 137-142. [CrossRef]

120. Kim, J.H.; Lee, C.H.; Lee, S.-W. Exosomal Transmission of MicroRNA from HCV Replicating Cells Stimulates Transdifferentiation in Hepatic Stellate Cells. Mol. Ther. Nucleic Acids 2019, 14, 483-497. [CrossRef]

121. Wilson, J.A.; Zhang, C.; Huys, A.; Richardson, C.D. Human Ago2 is required for efficient microRNA 122 regulation of hepatitis C virus RNA accumulation and translation. J. Virol. 2011, 85, 2342-2350. [CrossRef] [PubMed] 
122. Saha, B.; Kodys, K.; Adejumo, A.; Szabo, G. Circulating and Exosome-Packaged Hepatitis C Single-Stranded RNA Induce Monocyte Differentiation via TLR7/8 to Polarized Macrophages and Fibrocytes. J. Immunol. 2017, 198, 1974-1984. [CrossRef] [PubMed]

123. Virology: Coronaviruses. Nature 1968, 220, 650. [CrossRef]

124. Lai, M.M. Coronavirus: Organization, replication and expression of genome. Annu. Rev. Microbiol. 1990, 44, 303-333. [CrossRef]

125. Spaan, W.; Cavanagh, D.; Horzinek, M.C. Coronaviruses: Structure and genome expression. J. Gen. Virol. 1988, 69 Pt 12, 2939-2952. [CrossRef]

126. Gabutti, G.; d'Anchera, E.; Sandri, F.; Savio, M.; Stefanati, A. Coronavirus: Update Related to the Current Outbreak of COVID-19. Infect. Dis. Ther. 2020, 9, 241-253. [CrossRef]

127. Li, W.; Moore, M.J.; Vasilieva, N.; Sui, J.; Wong, S.K.; Berne, M.A.; Somasundaran, M.; Sullivan, J.L.; Luzuriaga, K.; Greenough, T.C.; et al. Angiotensin-converting enzyme 2 is a functional receptor for the SARS coronavirus. Nature 2003, 426, 450-454. [CrossRef]

128. To, K.F.; Lo, A.W.I. Exploring the pathogenesis of severe acute respiratory syndrome (SARS): The tissue distribution of the coronavirus (SARS-CoV) and its putative receptor, angiotensin-converting enzyme 2 (ACE2). J. Pathol. 2004, 203, 740-743. [CrossRef]

129. Hamming, I.; Timens, W.; Bulthuis, M.L.C.; Lely, A.T.; Navis, G.J.; van Goor, H. Tissue distribution of ACE2 protein, the functional receptor for SARS coronavirus. A first step in understanding SARS pathogenesis. J. Pathol. 2004, 203, 631-637. [CrossRef]

130. Jia, H.P.; Look, D.C.; Hickey, M.; Shi, L.; Pewe, L.; Netland, J.; Farzan, M.; Wohlford-Lenane, C.; Perlman, S.; McCray, P.B. Infection of human airway epithelia by SARS coronavirus is associated with ACE2 expression and localization. Adv. Exp. Med. Biol. 2006, 581, 479-484. [CrossRef]

131. de Wilde, A.H.; Snijder, E.J.; Kikkert, M.; van Hemert, M.J. Host Factors in Coronavirus Replication. In Roles of Host Gene and Non-coding RNA Expression in Virus Infection. Curr. Top. Microbiol. Immunol. 2017, 419, 1-42. [CrossRef]

132. Hoffmann, M.; Kleine-Weber, H.; Schroeder, S.; Krüger, N.; Herrler, T.; Erichsen, S.; Schiergens, T.S.; Herrler, G.; Wu, N.-H.; Nitsche, A.; et al. SARS-CoV-2 Cell Entry Depends on ACE2 and TMPRSS2 and Is Blocked by a Clinically Proven Protease Inhibitor. Cell 2020, 181, 271-280. [CrossRef] [PubMed]

133. Wrapp, D.; Wang, N.; Corbett, K.S.; Goldsmith, J.A.; Hsieh, C.-L.; Abiona, O.; Graham, B.S.; McLellan, J.S. Cryo-EM structure of the 2019-nCoV spike in the prefusion conformation. Science 2020, 367, 1260-1263. [CrossRef] [PubMed]

134. Glowacka, I.; Bertram, S.; Müller, M.A.; Allen, P.; Soilleux, E.; Pfefferle, S.; Steffen, I.; Tsegaye, T.S.; He, Y.; Gnirss, K.; et al. Evidence that TMPRSS2 activates the severe acute respiratory syndrome coronavirus spike protein for membrane fusion and reduces viral control by the humoral immune response. J. Virol. 2011, 85, 4122-4134. [CrossRef]

135. Iwata-Yoshikawa, N.; Okamura, T.; Shimizu, Y.; Hasegawa, H.; Takeda, M.; Nagata, N. TMPRSS2 Contributes to Virus Spread and Immunopathology in the Airways of Murine Models after Coronavirus Infection. J. Virol. 2019, 93. [CrossRef]

136. Matsuyama, S.; Nagata, N.; Shirato, K.; Kawase, M.; Takeda, M.; Taguchi, F. Efficient activation of the severe acute respiratory syndrome coronavirus spike protein by the transmembrane protease TMPRSS2. J. Virol. 2010, 84, 12658-12664. [CrossRef]

137. Shulla, A.; Heald-Sargent, T.; Subramanya, G.; Zhao, J.; Perlman, S.; Gallagher, T. A transmembrane serine protease is linked to the severe acute respiratory syndrome coronavirus receptor and activates virus entry. J. Virol. 2011, 85, 873-882. [CrossRef]

138. Walls, A.C.; Park, Y.-J.; Tortorici, M.A.; Wall, A.; McGuire, A.T.; Veesler, D. Structure, Function, and Antigenicity of the SARS-CoV-2 Spike Glycoprotein. Cell 2020, 181, 281-292.e6. [CrossRef]

139. Böttcher-Friebertshäuser, E.; Klenk, H.-D.; Garten, W. Activation of influenza viruses by proteases from host cells and bacteria in the human airway epithelium. Pathog. Dis. 2013, 69, 87-100. [CrossRef]

140. Bugge, T.H.; Antalis, T.M.; Wu, Q. Type II transmembrane serine proteases. J. Biol. Chem. 2009, 284, 23177-23181. [CrossRef]

141. Coutard, B.; Valle, C.; de Lamballerie, X.; Canard, B.; Seidah, N.G.; Decroly, E. The spike glycoprotein of the new coronavirus 2019-nCoV contains a furin-like cleavage site absent in $\mathrm{CoV}$ of the same clade. Antiviral Res. 2020, 176, 104742. [CrossRef] [PubMed] 
142. Kuba, K.; Imai, Y.; Rao, S.; Gao, H.; Guo, F.; Guan, B.; Huan, Y.; Yang, P.; Zhang, Y.; Deng, W.; et al. A crucial role of angiotensin converting enzyme 2 (ACE2) in SARS coronavirus-induced lung injury. Nat. Med. 2005, 11, 875-879. [CrossRef] [PubMed]

143. Totura, A.L.; Baric, R.S. SARS coronavirus pathogenesis: Host innate immune responses and viral antagonism of interferon. Curr. Opin. Virol. 2012, 2, 264-275. [CrossRef] [PubMed]

144. Ziegler, C.G.K.; Allon, S.J.; Nyquist, S.K.; Mbano, I.M.; Miao, V.N.; Tzouanas, C.N.; Cao, Y.; Yousif, A.S.; Bals, J.; Hauser, B.M.; et al. SARS-CoV-2 receptor ACE2 is an interferon-stimulated gene in human airway epithelial cells and is detected in specific cell subsets across tissues. Cell 2020, 181, 1-20. [CrossRef]

145. Zhao, X.; Guo, F.; Liu, F.; Cuconati, A.; Chang, J.; Block, T.M.; Guo, J.-T. Interferon induction of IFITM proteins promotes infection by human coronavirus OC43. Proc. Natl. Acad. Sci. USA 2014, 111, 6756-6761. [CrossRef]

146. Prokunina-Olsson, L.; Alphonse, N.; Dickenson, R.E.; Durbin, J.E.; Glenn, J.S.; Hartmann, R.; Kotenko, S.V.; Lazear, H.M.; O'Brien, T.R.; Odendall, C.; et al. COVID-19 and emerging viral infections: The case for interferon lambda. J. Exp. Med. 2020, 217, e20200653. [CrossRef]

147. Channappanavar, R.; Fehr, A.R.; Vijay, R.; Mack, M.; Zhao, J.; Meyerholz, D.K.; Perlman, S. Dysregulated Type I Interferon and Inflammatory Monocyte-Macrophage Responses Cause Lethal Pneumonia in SARS-CoV-Infected Mice. Cell Host Microbe 2016, 19, 181-193. [CrossRef]

148. Li, G.; De Clercq, E. Therapeutic options for the 2019 novel coronavirus (2019-nCoV). Nat. Rev. Drug Discov. 2020, 19, 149-150. [CrossRef]

149. Dong, L.; Hu, S.; Gao, J. Discovering drugs to treat coronavirus disease 2019 (COVID-19). Drug Discov. Ther. 2020, 14, 58-60. [CrossRef]

150. Lei, J.; Li, J.; Li, X.; Qi, X. CT Imaging of the 2019 Novel Coronavirus (2019-nCoV) Pneumonia. Radiology 2020, 295, 18. [CrossRef]

151. Cheng, V.C.C.; Lau, S.K.P.; Woo, P.C.Y.; Yuen, K.Y. Severe acute respiratory syndrome coronavirus as an agent of emerging and reemerging infection. Clin. Microbiol. Rev. 2007, 20, 660-694. [CrossRef] [PubMed]

152. den Boon, J.A.; Ahlquist, P. Organelle-like membrane compartmentalization of positive-strand RNA virus replication factories. Annu. Rev. Microbiol. 2010, 64, 241-256. [CrossRef] [PubMed]

153. Knoops, K.; Kikkert, M.; van den Worm, S.H.E.; Zevenhoven-Dobbe, J.C.; van der Meer, Y.; Koster, A.J.; Mommaas, A.M.; Snijder, E.J. SARS-Coronavirus Replication Is Supported by a Reticulovesicular Network of Modified Endoplasmic Reticulum. PLoS Biol. 2008, 6, e226. [CrossRef]

154. Ulasli, M.; Verheije, M.H.; de Haan, C.A.M.; Reggiori, F. Qualitative and quantitative ultrastructural analysis of the membrane rearrangements induced by coronavirus. Cell. Microbiol. 2010, 12, 844-861. [CrossRef]

155. Maier, H.J.; Hawes, P.C.; Cottam, E.M.; Mantell, J.; Verkade, P.; Monaghan, P.; Wileman, T.; Britton, P. Infectious bronchitis virus generates spherules from zippered endoplasmic reticulum membranes. mBio 2013, 4, e00801-e00813. [CrossRef] [PubMed]

156. Hagemeijer, M.C.; Rottier, P.J.M.; de Haan, C.A.M. Biogenesis and dynamics of the coronavirus replicative structures. Viruses 2012, 4, 3245-3269. [CrossRef]

157. Gosert, R.; Kanjanahaluethai, A.; Egger, D.; Bienz, K.; Baker, S.C. RNA replication of mouse hepatitis virus takes place at double-membrane vesicles. J. Virol. 2002, 76, 3697-3708. [CrossRef]

158. Qian, Z.; Travanty, E.A.; Oko, L.; Edeen, K.; Berglund, A.; Wang, J.; Ito, Y.; Holmes, K.V.; Mason, R.J. Innate immune response of human alveolar type II cells infected with severe acute respiratory syndrome-coronavirus. Am. J. Respir. Cell Mol. Biol. 2013, 48, 742-748. [CrossRef]

159. Maier, H.J.; Britton, P. Involvement of autophagy in coronavirus replication. Viruses 2012, 4, 3440-3451. [CrossRef]

160. de Haan, C.A.M.; Reggiori, F. Are nidoviruses hijacking the autophagy machinery? Autophagy 2008, 4, $276-279$. [CrossRef]

161. Angelini, M.M.; Akhlaghpour, M.; Neuman, B.W.; Buchmeier, M.J. Severe acute respiratory syndrome coronavirus nonstructural proteins 3, 4, and 6 induce double-membrane vesicles. mBio 2013, 4, e00524-13. [CrossRef] [PubMed]

162. Oudshoorn, D.; Rijs, K.; Limpens, R.W.A.L.; Groen, K.; Koster, A.J.; Snijder, E.J.; Kikkert, M.; Bárcena, M. Expression and Cleavage of Middle East Respiratory Syndrome Coronavirus nsp3-4 Polyprotein Induce the Formation of Double-Membrane Vesicles That Mimic Those Associated with Coronaviral RNA Replication. mBio 2017, 8, e01658-17. [CrossRef] [PubMed] 
163. Basso, L.G.M.; Vicente, E.F.; Crusca, E.; Cilli, E.M.; Costa-Filho, A.J. SARS-CoV fusion peptides induce membrane surface ordering and curvature. Sci. Rep. 2016, 6, 37131. [CrossRef] [PubMed]

164. Vennema, H.; Godeke, G.J.; Rossen, J.W.; Voorhout, W.F.; Horzinek, M.C.; Opstelten, D.J.; Rottier, P.J. Nucleocapsid-independent assembly of coronavirus-like particles by co-expression of viral envelope protein genes. EMBO J. 1996, 15, 2020-2028. [CrossRef] [PubMed]

165. Bobrie, A.; Colombo, M.; Raposo, G.; Théry, C. Exosome secretion: Molecular mechanisms and roles in immune responses. Traffic 2011, 12, 1659-1668. [CrossRef]

166. Zhou, X.; Xie, F.; Wang, L.; Zhang, L.; Zhang, S.; Fang, M.; Zhou, F. The function and clinical application of extracellular vesicles in innate immune regulation. Cell. Mol. Immunol. 2020, 17, 323-334. [CrossRef]

167. Anderson, M.R.; Kashanchi, F.; Jacobson, S. Exosomes in Viral Disease. Neurotherapeutics 2016, 13, 535-546. [CrossRef]

168. Khatua, A.K.; Taylor, H.E.; Hildreth, J.E.K.; Popik, W. Exosomes packaging APOBEC3G confer human immunodeficiency virus resistance to recipient cells. J. Virol. 2009, 83, 512-521. [CrossRef]

169. Deschamps, T.; Kalamvoki, M. Extracellular Vesicles Released by Herpes Simplex Virus 1-Infected Cells Block Virus Replication in Recipient Cells in a STING-Dependent Manner. J. Virol. 2018, 92, e01102-18. [CrossRef]

170. Yáñez-Mó, M.; Siljander, P.R.-M.; Andreu, Z.; Zavec, A.B.; Borràs, F.E.; Buzas, E.I.; Buzas, K.; Casal, E.; Cappello, F.; Carvalho, J.; et al. Biological properties of extracellular vesicles and their physiological functions. J. Extracell. Vesicles 2015, 4, 27066. [CrossRef]

171. Sun, D.; Zhuang, X.; Xiang, X.; Liu, Y.; Zhang, S.; Liu, C.; Barnes, S.; Grizzle, W.; Miller, D.; Zhang, H.-G. A novel nanoparticle drug delivery system: The anti-inflammatory activity of curcumin is enhanced when encapsulated in exosomes. Mol. Ther. 2010, 18, 1606-1614. [CrossRef] [PubMed]

172. Di Bonito, P.; Ridolfi, B.; Columba-Cabezas, S.; Giovannelli, A.; Chiozzini, C.; Manfredi, F.; Anticoli, S.; Arenaccio, C.; Federico, M. HPV-E7 delivered by engineered exosomes elicits a protective CD8 ${ }^{+} \mathrm{T}$ cell-mediated immune response. Viruses 2015, 7, 1079-1099. [CrossRef] [PubMed]

173. Anticoli, S.; Manfredi, F.; Chiozzini, C.; Arenaccio, C.; Olivetta, E.; Ferrantelli, F.; Capocefalo, A.; Falcone, E.; Ruggieri, A.; Federico, M. An Exosome-Based Vaccine Platform Imparts Cytotoxic T Lymphocyte Immunity Against Viral Antigens. Biotechnol. J. 2018, 13, e1700443. [CrossRef] [PubMed]

174. Kuate, S.; Cinatl, J.; Doerr, H.W.; Uberla, K. Exosomal vaccines containing the S protein of the SARS coronavirus induce high levels of neutralizing antibodies. Virology 2007, 362, 26-37. [CrossRef] 